Article

\title{
Silver(I) and Copper(I) Complexation with Decachloro-Closo-Decaborate Anion
}

\author{
Varvara V. Avdeeva ${ }^{1, *(D)}$, Grigoriy A. Buzanov ${ }^{1}$, Elena A. Malinina ${ }^{1}$, Nikolay T. Kuznetsov ${ }^{1}$ \\ and Anna V. Vologzhanina $2, * \mathbb{D}$ \\ 1 Kurnakov Institute of General and Inorganic Chemistry, Russian Academy of Sciences, Leninskii pr. 31, \\ Moscow 119991, Russia; gbuzanov@yandex.ru (G.A.B.); malinina@igic.ras.ru (E.A.M.); \\ ntkuz@igic.ras.ru (N.T.K.) \\ 2 Nesmeyanov Institute of Organoelement Compounds, Russian Academy of Sciences Vavilova str. 28, \\ Moscow 119991, Russia \\ * Correspondence: avdeeva.varvara@mail.ru (V.V.A.); vologzhanina@mail.ru (A.V.V.)
}

Received: 21 April 2020; Accepted: 8 May 2020; Published: 10 May 2020

\begin{abstract}
A series of complexation reactions of silver(I) and copper(I) in the presence of a polyhedral weakly coordinating $\left[\mathrm{B}_{10} \mathrm{Cl}_{10}\right]^{2-}$ anion has been carried out. The effect of the solvent and the presence of $\mathrm{Ph}_{3} \mathrm{P}$ on the composition and structure of the reaction product were studied. Eight novel complexes were obtained and characterized by ${ }^{11} \mathrm{~B}$ Nuclear magnetic resonance, Infra-Red, and Raman spectroscopies as well as powder and single-crystal $\mathrm{X}$-ray diffraction techniques. The $\left[\mathrm{B}_{10} \mathrm{Cl}_{10}\right]^{2-}$ anion demonstrated weaker coordinating ability towards coinage metals than $\left[\mathrm{B}_{10} \mathrm{H}_{10}\right]^{2-}$ at similar reaction conditions. The $\left[\mathrm{B}_{10} \mathrm{Cl}_{10}\right]^{2-}$ anion remains unreacted in the copper(I) complexation reaction, while in the absence of competing ligands, we obtained the first complexes containing decachloro-closo-decaborate anion directly coordinated by the metal atom. The bonding between metal atoms and the boron cluster anions was studied using the atomic Hirshfeld surfaces. Besides edge and face coordination of the polyhedral anion, this method allowed us to reveal the Ag-Ag bond in crystal of $\left\{\mathrm{Ag}_{2}(\mathrm{DMF})_{2}\left[\mathrm{~B}_{10} \mathrm{Cl}_{10}\right]\right\}_{n}$, the presence of which was additionally supported by the Raman spectroscopy data.
\end{abstract}

Keywords: atomic Hirshfeld surface; boron cluster; copper(I); decachloro-closo-decaborate anion; decahydro-closo-decaborate anion; silver(I)

\section{Introduction}

Boron cluster anions and their analogs, carboranes and metallocarboranes [1-4], are fascinating objects in modern inorganic and organoboron chemistry because of their geometric and electronic structures and promising properties. Possessing 3D aromaticity and a tendency to participate in reactions of electrophilic and nucleophilic substitution, boron clusters form numerous derivatives with exo-polyhedral substituents [5-7]. In addition, boron cluster anions form complexes and salts with different composition and structure [8-10]. Boron clusters are used to design compounds that can be applied in boron neutron capture therapy, for radionuclide diagnostics and therapy, in catalysis, for preparation of safety coatings and thermally stable polymers, extraction of radionuclides, etc. [11-15].

Boron clusters and their derivatives are considered as soft Lewis bases because of their large size and relatively low charge; quite logically, they form a great variety of inner-sphere complexes with metals that are soft Lewis acids, such as silver(I), copper(I), lead(II), etc. Different positions of metal atoms around a bulky boron cage results in the preparation of positional isomers of mononuclear and binuclear copper(I) and silver(I) complexes, which are discussed in detail in references [16-18]. 
In crystallography, polyhedral boranes and carboranes and their halogen derivatives are considered weakly coordinating anions [19-22], and X-ray diffraction data allow metal atoms and various polyhedral boranes to be ranked in accord with their ability to form salts or complexes. For partially substituted halogen derivatives of boron cages, competition between halogen atoms and unsubstituted BH groups to form M ... Hal-B or three-centered two-electron MHB bonds can give an insight about the relative coordination ability of a boron cage and its (per)halogenated analog. For example, in the structure of two silver mononuclear complexes $\left[\mathrm{Ag}\left(\mathrm{Ph}_{4} \mathrm{P}\right)_{4}\right]\left[\mathrm{Ag}\left(\mathrm{Ph}_{3} \mathrm{P}\right)_{2}[\mathrm{An}]\right]$, where $[\mathrm{An}]$ are the $\left[\mathrm{B}_{10} \mathrm{H}_{10}\right]^{2-}$ and $\left[\mathrm{B}_{10} \mathrm{H}_{9} \mathrm{Cl}\right]^{2-}$ anions cocrystallized [17] (positional isomers with an equatorial and an apical edges coordinated), it has been found that the monosubstituted anion $\left[\mathrm{B}_{10} \mathrm{H}_{9} \mathrm{Cl}\right]^{2-}$ in both isomers is coordinated by the metal atom through the appropriate edge opposite to the chlorine atom introduced into the boron cage. Thus, one can propose that decahydro-closo-decaborate has stronger coordinating ability toward a silver(I) atom than its perchlorinated derivative. Indeed, the decachloro-closo-decaborate anion acts as a counterion in X-rayed complexes of copper(II) [23], cobalt(II) [24], and manganese(II) [25] complexes with phen (1,10-phenanthroline) and bipy (2,2-bipyridyl), and of silver complex of the $\left[\mathrm{Ag}\left(\mathrm{NH}_{3}\right)_{2}\right]_{2}\left[\mathrm{~B}_{10} \mathrm{Cl}_{10}\right]$ composition [26]. For the latter complex, weak non-bonding Ag ... Cl interactions as long as 3.25-3.41 $\AA$ manifest themselves in ${ }^{35} \mathrm{Cl} \mathrm{NQR}$ spectra; thus, X-ray diffraction and associated methods of analysis of chemical bonding remain the best choice to reveal any $\mathrm{M}$... Hal-B bonding.

In contrast with $\left[\mathrm{B}_{10} \mathrm{Cl}_{10}\right]^{2-}$ complexes, chloro-, bromo- and iododerivatives of carboranes and a dodecaborane are better represented in the Cambridge Structural Database [27] (see, for example, references [28-35]). Thus, in this study we investigate the coordination ability of the $\left[\mathrm{B}_{10} \mathrm{Cl}_{10}\right]^{2-}$ anion towards silver(I) and copper(I) atoms in the absence of $\mathrm{N}$-donor ligands. Complexation reactions in the presence of $\mathrm{Ph}_{3} \mathrm{P}$ and without it were carried out; and various solvents were attested that allowed the first complexes of coordinated $\left[\mathrm{B}_{10} \mathrm{Cl}_{10}\right]^{2-}$ to be obtained, and $\mathrm{Ag} \ldots \mathrm{Cl}-\mathrm{B}$ bonds in these complexes can be compared with those in silver(I) complexes with chlorocarboranes and dodecacloro-closo-dodecaborane.

\section{Experimental}

\subsection{Synthesis}

Commercially available organic solvents (HPLC acetonitrile and DMF) and anhydrous $\mathrm{Ph}_{3} \mathrm{P}$ were purchased from Aldrich (St. Louis, MO, USA). All the reactions were carried out in air. $\left[\mathrm{HNEt}_{3}\right]_{2}\left[\mathrm{~B}_{10} \mathrm{H}_{10}\right]$ was synthesized from decaborane-14 according to the known procedure [36]. The reaction between $\left[\mathrm{HNEt}_{3}\right]_{2}\left[\mathrm{~B}_{10} \mathrm{H}_{10}\right]$ and $\mathrm{KOH}$ afforded $\mathrm{K}_{2}\left[\mathrm{~B}_{10} \mathrm{H}_{10}\right]$ with release of $\mathrm{Et}_{3} \mathrm{~N}$. Chlorination of aqueous $\mathrm{K}_{2}\left[\mathrm{~B}_{10} \mathrm{H}_{10}\right]$ by chlorine was carried out in accordance with the procedure reported [37] to form $\mathrm{K}_{2}\left[\mathrm{~B}_{10} \mathrm{Cl}_{10}\right]$. [ $\left.\mathrm{HNEt}_{3}\right]_{2}\left[\mathrm{~B}_{10} \mathrm{Cl}_{10}\right]$ precipitated from aqueous solutions of $\mathrm{K}_{2}\left[\mathrm{~B}_{10} \mathrm{Cl}_{10}\right]$ and the corresponding alkylammonium chloride as reported in Reference [26]. $\left[\mathrm{Ag}\left(\mathrm{Ph}_{3} \mathrm{P}\right)_{3} \mathrm{NO}_{3}\right]$ was synthesized according to the method reported in Reference [38]. [ $\left.\mathbf{C u}\left(\mathrm{Ph}_{3} \mathbf{P}\right)_{3} \mathbf{C l}\right]$ was synthesized according to the known procedure [39]

[Ag(PPh $\left.)_{2}(\mathbf{D M F})_{2}\right]_{2}\left[\mathbf{B}_{10} \mathrm{Cl}_{10}\right](\mathbf{1})$ A solution of $\mathrm{Ph}_{3} \mathrm{P}(4 \mathrm{mmol})$ in DMF $(10 \mathrm{~mL})$ was added to a DMF solution $(10 \mathrm{~mL})$ containing $\mathrm{AgNO}_{3}(2 \mathrm{mmol})$ and $\left(\mathrm{Et}_{3} \mathrm{NH}\right)_{2}\left[\mathrm{~B}_{10} \mathrm{Cl}_{10}\right](1 \mathrm{mmol})$. The resulting colorless solution was allowed to stand at room temperature in air. Slow evaporation of the reaction solution (about a week) gave compound 1 as colorless crystals $1 \cdot 2 \mathrm{DMF}$ (yield, 74\%). The resulting crystals were filtered off and dried in air. Single crystal $1 \cdot 2 \mathrm{DMF}$ used for X-ray diffraction was chosen directly from the reaction mixture. ${ }^{11} \mathrm{~B}$ NMR $\left(64.297 \mathrm{MHz},\left[\mathrm{D}_{7}\right] \mathrm{DMF}, 25^{\circ} \mathrm{C}\right): \delta=4.65\left(2 \mathrm{~B}, \mathrm{~s}, \mathrm{~B}_{\mathrm{ap}}\right)$; -2.71 (8B, s, $\mathrm{B}_{\text {eq }}$ ); IR (NaCl, Nujol mull, $\mathrm{cm}^{-1}$ ): 1665s, 1309, 1182, 1158s, 1093s, 1002s, 846, 745s, 695s; elemental analysis calcd (\%) for $\mathrm{Ag}_{2} \mathrm{C}_{90} \mathrm{H}_{102} \mathrm{~B}_{10} \mathrm{Cl}_{10} \mathrm{~N}_{6} \mathrm{O}_{6} \mathrm{P}_{4}$ (2166.08): Ag 9.96, C 49.90, H 4.75, N 3.88, B 4.99; found: $\mathrm{Ag} 10.02, \mathrm{C} 49.81, \mathrm{H} 4.65, \mathrm{~N} 3.78, \mathrm{~B} 5.03$.

$\left[\mathbf{A g}\left(\mathbf{P P h}_{3}\right)_{3}\left(\mathbf{H}_{2} \mathbf{O}\right)\right]_{2}\left[\mathbf{B}_{10} \mathbf{C l}_{10}\right]$ (2) A solution of $\left[\mathrm{Ag}\left(\mathrm{Ph}_{3} \mathrm{P}\right)_{3} \mathrm{NO}_{3}\right](6 \mathrm{mmol})$ in DMF (10 mL) was added to a DMF solution $(10 \mathrm{~mL})$ containing $\left(\mathrm{Et}_{3} \mathrm{NH}\right)_{2}\left[\mathrm{~B}_{10} \mathrm{Cl}_{10}\right](3 \mathrm{mmol})$. Slow evaporation of the 
reaction solution in air (about $72 \mathrm{~h}$ ) gave compound 2 as colorless crystals $2 \cdot 4$ DMF $(76 \%)$. The resulting crystals were filtered off and dried in air. Single crystal 2 4 DMF used for X-ray diffraction was chosen directly from the reaction mixture. IR ( $\mathrm{NaCl}$, Nujol mull): 3524, 3461w, 1665s, 1157s, 1093s, 1004s; 1093, 846, 745s, 695s; elemental analysis calcd (\%) for $\mathrm{Ag}_{2} \mathrm{C}_{120} \mathrm{H}_{122} \mathrm{~B}_{10} \mathrm{Cl}_{10} \mathrm{~N}_{4} \mathrm{O}_{6} \mathrm{P}_{6}$ (2580.49): $\mathrm{Ag}$ 8.36, C 55.85, H 4.77, B 4.19; found: Ag 8.24, C 55.79, H 4.69, B 4.13.

$\left[\mathrm{Cu}\left(\mathrm{Ph}_{3} \mathrm{P}\right)_{3} \mathrm{Cl}\right] \cdot 2 \mathrm{DMF}(3 \cdot 2 \mathrm{DMF})$ and $\left[\mathrm{Cu}_{2}\left(\mathrm{Ph}_{3} \mathrm{P}\right)_{3}(\mu-\mathrm{Cl})_{2}\right](4)$ A solution of $\left[\mathrm{Cu}\left(\mathrm{Ph}_{3} \mathrm{P}\right)_{3} \mathrm{Cl}\right]$ $(6 \mathrm{mmol})$ in DMF $(10 \mathrm{~mL})$ was added to a DMF solution $(10 \mathrm{~mL})$ containing $\left(\mathrm{Et}_{3} \mathrm{NH}\right)_{2}\left[\mathrm{~B}_{10} \mathrm{Cl}_{10}\right](3 \mathrm{mmol})$. Slow evaporation of the reaction solution in air (about $36 \mathrm{~h}$ ) gave a mixture of compounds $3 \cdot 2 \mathrm{DMF}$ and 4 as colorless crystals. The resulting crystals were filtered off and dried in air. Single crystals 3 . 2DMF and 4 suitable for $\mathrm{X}$-ray diffraction studies were chosen directly from the reaction mixture.

$\left[\mathbf{A g}\left(\mathbf{P h}_{3} \mathbf{P}\right)_{4}\right]\left[\mathbf{A g}\left(\mathbf{P h}_{3} \mathbf{P}\right)_{2}\left[\mathbf{B}_{10} \mathbf{H}_{10}\right]\right](5)$ A solution of $\left[\mathrm{Ag}\left(\mathrm{Ph}_{3} \mathrm{P}\right)_{3} \mathrm{NO}_{3}\right](6 \mathrm{mmol})$ in DMF (10 mL) was added to a DMF solution $(10 \mathrm{~mL})$ containing $\left(\mathrm{Et}_{3} \mathrm{NH}\right)_{2}\left[\mathrm{~B}_{10} \mathrm{H}_{10}\right](3 \mathrm{mmol})$. Slow evaporation of the reaction solution in air (about $72 \mathrm{~h}$ ) gave compound 5 as colorless crystals (yield, 79\%). The resulting crystals were filtered off and dried in air. Single crystal $\mathbf{5} \cdot 0.1 \mathrm{H}_{2} \mathrm{O}$ was used for $\mathrm{X}$-ray diffraction. ${ }^{11} \mathbf{B}$ NMR (64.297 MHz, [D $\left.\mathrm{D}_{7} \mathrm{DMF}, 25^{\circ} \mathrm{C}\right): \delta=1.19$ (2B, d, Bap); -29.27 (8B, d, Beq); IR (NaCl, Nujol mull, $\mathrm{cm}^{-1}$ ): 2451br, 2299br, 1673w, 1310, 1159, 1093s, 1027, 998, 745s, 695s; elemental analysis calcd (\%) for $\mathrm{Ag}_{2} \mathrm{C}_{108} \mathrm{H}_{100} \mathrm{~B}_{10} \mathrm{P}_{6}$ (1907.63): Ag 11.31, C 68.00, H 5.28, B 5.67; found: Ag 11.24, C 59.96, H 5.19, B 5.63.

$\left[\mathrm{Ag}_{2}\left[\mathbf{B}_{10} \mathrm{Cl}_{10}\right]\right]_{n}(\mathbf{6})$ A solution of $\mathrm{AgNO}_{3}(6 \mathrm{mmol})$ in water $(10 \mathrm{~mL})$ was added to a water solution $(10 \mathrm{~mL})$ containing $\mathrm{K}_{2}\left[\mathrm{~B}_{10} \mathrm{Cl}_{10}\right](3 \mathrm{mmol})$. The resulting colorless solution was allowed to stand in air at room temperature gradually acquiring grey color. Grey crystals 6 and white powder $\mathrm{KNO}_{3}$ precipitated after $72 \mathrm{~h}$, when water was almost completely evaporated (yield, 95\%). For physicochemical studies, grey crystals were chosen mechanically from the mixture. ${ }^{11} \mathbf{B}$ NMR $\left(64.297 \mathrm{MHz},\left[\mathrm{D}_{7}\right] \mathrm{DMF}, 25^{\circ} \mathrm{C}\right)$ : $\delta=4.34\left(2 \mathrm{~B}, \mathrm{~s}, \mathrm{~B}_{\mathrm{ap}}\right)$; $-2.85\left(8 \mathrm{~B}, \mathrm{~s}, \mathrm{~B}_{\mathrm{eq}}\right)$; IR (NaCl, Nujol mull, cm $\left.\mathrm{cm}^{-1}\right)$ : 1159, 1007, 850, 744; Raman $\left(\mathrm{cm}^{-1}\right)$ : 2936, 2310, 2284, 1369, 1151, 937, 734, 564, 385, 309s, 281, 111; elemental analysis calcd (\%) for $\mathrm{Ag}_{2} \mathrm{~B}_{10} \mathrm{Cl}_{10}$ (678.38): $\mathrm{Ag} 31.80$ B 15.94; found: $\mathrm{Ag} 31.65$, B 15.79 .

$\left[\mathbf{A g}_{2}(\mathbf{D M F})_{2}\left[\mathbf{B}_{10} \mathrm{Cl}_{10}\right]\right]_{n}(7)$ A solution of $\mathrm{AgNO}_{3}(6 \mathrm{mmol})$ in $\mathrm{DMF}(10 \mathrm{~mL})$ was added to a DMF solution $(10 \mathrm{~mL})$ containing $\left(\mathrm{Et}_{3} \mathrm{NH}\right)_{2}\left[\mathrm{~B}_{10} \mathrm{Cl}_{10}\right](3 \mathrm{mmol})$. The resulting colorless solution was allowed to stand in air at room temperature gradually acquiring black color because of partial reduction of silver. Slow evaporation of the reaction solution in air (about $72 \mathrm{~h}$ ) gave compound 7 as grey crystals $(65 \%)$. The resulting crystals were filtered off and dried in air. Single crystal 6 chosen directly from the reaction solution was used for X-ray diffraction studies. IR $\left(\mathrm{NaCl}, \mathrm{Nujol}\right.$ mull, $\left.\mathrm{cm}^{-1}\right)$ : 1665 , 1159, 1007, 849, 745; Raman (cm $\left.{ }^{-1}\right)$ : 1600, 1386, 1127, 1069s, 845, 308s, 185; elemental analysis calcd (\%) for $\mathrm{Ag}_{2} \mathrm{C}_{6} \mathrm{H}_{14} \mathrm{~N}_{2} \mathrm{O}_{2} \mathrm{~B}_{10} \mathrm{Cl}_{10}$ (824.56): $\mathrm{Ag} 26.16, \mathrm{C}$ 8.74, $\mathrm{H}$ 1.71, B 13.11; found: $\mathrm{Ag} 26.07, \mathrm{C} 8.62$, H 1.63, B 13.13.

$\left[\mathrm{Ag}_{2}\left(\mathrm{CH}_{3} \mathrm{CN}\right)_{2}\left[\mathrm{~B}_{10} \mathrm{Cl}_{10}\right]\right]_{n}(8)$ A solution of $\mathrm{AgNO}_{3}(6 \mathrm{mmol})$ in acetonitrile $(10 \mathrm{~mL})$ was added to a solution containing $\mathrm{K}_{2}\left[\mathrm{~B}_{10} \mathrm{Cl}_{10}\right](3 \mathrm{mmol})$ in acetonitrile $(10 \mathrm{~mL})$. White powder $\mathrm{KNO}_{3}$ precipitated from the reaction mixture immediately after fusing both solutions, which was filtered off. The resulting colorless mother solution was allowed to stand in air at room temperature. Slow evaporation of the reaction solution in air (about $24 \mathrm{~h}$ ) gave compound 8 as white crystals (95\%). The resulting crystals were filtered off and dried in air. Single crystal 8 chosen directly from the reaction solution was used for X-ray diffraction studies. IR ( $\mathrm{NaCl}$, Nujol mull, $\mathrm{cm}^{-1}$ ): 2314, 2287, 1157, 1003, 845, 721; Raman $\left(\mathrm{cm}^{-1}\right):$ 2936, 2311, 2285, 1369, 1152, 1046, 937, 735, 265, 309s, 282, 111; elemental analysis calcd (\%) for $\mathrm{Ag}_{2} \mathrm{C}_{8} \mathrm{H}_{12} \mathrm{~N}_{4} \mathrm{~B}_{10} \mathrm{Cl}_{10}$ (842.58): $\mathrm{Ag} 25.60, \mathrm{C} 11.40, \mathrm{H} 1.44, \mathrm{~N}$ 6.65; B 12.83; found: $\mathrm{Ag}$ 25.27, C 11.19, H 1.51, N 6.48, B 12.94 .

\subsection{Methods}

Elemental analysis for carbon and hydrogen was carried out on a Carlo Erba CHNS-3 FA 1108 automated elemental analyzer (Carlo Erba Instruments, Milan, Italy). Determination of boron and metals was performed on an iCAP 6300 Duo ICP emission spectrometer (Thermo Scientific, Waltham, MA, USA) with inductively coupled plasma. For elemental analysis, samples were dried in vacuum to 
constant weight. IR spectra of compounds were recorded on a Lumex Infralum FT-02 Fourier-transform spectrophotometer in the range of $4000-600 \mathrm{~cm}^{-1}$ at a resolution of $1 \mathrm{~cm}^{-1}$. Samples were prepared as Nujol mulls (Aldrich, St. Louis, MO, USA); $\mathrm{NaCl}$ pellets were used. Raman spectra of solid samples of compounds 6-8 were measured using a VERTEX 70 spectrometer (Bruker Optics, Ettlingen, Germany) equipped with a RAM II FT-Raman module. IR spectra of complexes 1-8 and Raman spectra of 6-8 are shown in Figures S1-S7 (see Electronic Supporting Information, ESI). ${ }^{11} \mathrm{~B}$ NMR spectra of compounds 1, 5, and $\mathbf{6}$ in $\left[\mathrm{D}_{7}\right] \mathrm{DMF}$ were recorded on a Bruker AC 200 spectrometer (Bruker AXC, Inc., Karlsruhe, Germany) at a frequency of $64.297 \mathrm{MHz}$ using $\mathrm{BF}_{3} \cdot \mathrm{Et}_{2} \mathrm{O}$ as an external standard.

\subsection{X-ray Diffraction}

For single-crystal X-ray diffraction, the intensities of reflections were collected with a Bruker Apex II CCD diffractometer with $\mathrm{MoK}_{\alpha}$ radiation $(\lambda=0.71073 \AA$, graphite monochromator). Single crystals of 1-8 were obtained from reaction mixtures. Intensities of the reflections were measured with a Bruker Apex II CCD diffractometer (Bruker AXS, Inc., Madison, WI, USA) using graphite monochromated $\mathrm{MoK}_{\alpha}$ radiation $(\lambda=0.71073 \AA)$. The structures were solved by direct method and refined by full-matrix least squares against $\mathrm{F}^{2}$. Non-hydrogen atoms were refined anisotropically, except for some disordered fragments. The boron cage in $\mathbf{5}$ is equally disordered over two sites, and boron atoms of the cage were refined isotropically. Positions of hydrogen atoms were calculated, and all hydrogen atoms were included in the refinement by the riding model with $\mathrm{U}_{\text {iso }}(\mathrm{H})=1.5 \mathrm{U}_{\mathrm{eq}}(\mathrm{X})$ for methyl groups and water molecules, and $=1.2 \mathrm{U}_{\mathrm{eq}}(\mathrm{X})$ for the other atoms. All calculations were made using the SHELXL2014 [40] and OLEX2 [41] program packages. Experimental details and crystal parameters are listed in Table 1.

The crystallographic data for 1-8 have been deposited with the Cambridge Crystallographic Data Centre (CCDC no. 1937727-1937734). These data can be obtained free of charge via http://www.ccdc.cam.ac.uk/structures/.

The X-ray powder diffraction patterns for $\mathbf{1} \cdot 2 \mathrm{DMF}, \mathbf{6}$, and $\mathbf{7}$ were obtained on a Bruker D8 Advance Vario diffractometer equipped with a Ge(111) monochromator and a LynxEye position-sensitive detector $\left(\mathrm{CuK}_{\alpha}\right.$ radiation, $\lambda=1.540596 \AA$, (Bruker AXS, Inc., Madison, WI, USA) at the Shared Equipment Center of the Kurnakov Institute (IGIC RAS). The X-ray powder diffraction data agrees with the calculated X-ray single crystal data, indicating that each sample predominately represents a single phase (Figures S9-S11, see ESI). 
Table 1. X-ray crystallographic data for complexes 1-8.

\begin{tabular}{|c|c|c|c|c|c|c|c|c|}
\hline Parameter & 1.2DMF & $2 \cdot 4 \mathrm{DMF}$ & $3 \cdot 2 \mathrm{DMF}$ & 4 & $5 \cdot 0.1 \mathrm{H}_{2} \mathrm{O}$ & 6 & 7 & 8 \\
\hline $\begin{array}{l}\text { Formula } \\
\text { Fw }\end{array}$ & $\begin{array}{c}\mathrm{C}_{90} \mathrm{H}_{102} \mathrm{Ag}_{2} \mathrm{~B}_{10} \mathrm{Cl}_{10} \mathrm{~N}_{6} \mathrm{O}_{6} \mathrm{P}_{4} \\
2165.99\end{array}$ & $\begin{array}{c}\mathrm{C}_{120} \mathrm{H}_{122} \mathrm{Ag}_{2} \mathrm{~B}_{10} \mathrm{Cl}_{10} \mathrm{~N}_{4} \mathrm{O}_{6} \mathrm{P}_{6} \\
2580.37\end{array}$ & $\begin{array}{c}\mathrm{C}_{60} \mathrm{H}_{59} \mathrm{ClCuN}_{2} \mathrm{O}_{2} \mathrm{P}_{3} \\
1031.99\end{array}$ & $\begin{array}{c}\mathrm{C}_{54} \mathrm{H}_{45} \mathrm{Cl}_{2} \mathrm{Cu}_{2} \mathrm{P}_{3} \\
984.76\end{array}$ & $\begin{array}{c}\mathrm{C}_{108} \mathrm{H}_{100.2} \mathrm{Ag}_{2} \mathrm{~B}_{10} \mathrm{O}_{0.1} \mathrm{P}_{6} \\
1909.34\end{array}$ & $\begin{array}{c}\mathrm{Ag}_{2} \mathrm{~B}_{10} \mathrm{Cl}_{10} \\
678.34\end{array}$ & $\begin{array}{c}\mathrm{C}_{6} \mathrm{H}_{14} \mathrm{Ag}_{2} \mathrm{~B}_{10} \mathrm{Cl}_{10} \mathrm{~N}_{2} \mathrm{O}_{2} \\
824.52\end{array}$ & $\underset{842.56}{\mathrm{C}_{8} \mathrm{H}_{12} \mathrm{Ag}_{2} \mathrm{~B}_{10} \mathrm{Cl}_{10} \mathrm{~N}_{4}}$ \\
\hline $\begin{array}{l}\text { Crystal system, space } \\
\text { group }\end{array}$ & Monoclinic, $\mathrm{C} 2 / \mathrm{c}$ & Monoclinic, $\mathrm{C} 2 / \mathrm{c}$ & Triclinic, $P \overline{1}$ & Monoclinic, $P 2_{1} / c$ & Triclinic, $P \overline{1}$ & Hexagonal, $P 6_{2} 22$ & Monoclinic, $C_{2} / c$ & Tetragonal, $P 4_{1} 2_{1} 2$ \\
\hline $\mathrm{T}(\mathrm{K})$ & $120.0(2)$ & $120.0(2)$ & $120.0(2)$ & $120.0(2)$ & $120.0(2)$ & $120.0(2)$ & $120.0(2)$ & $120.0(2)$ \\
\hline $\mathrm{a}(\AA)$ & $36.319(2)$ & $37.202(3)$ & $10.6772(4)$ & $18.942(2)$ & $13.5059(6)$ & $9.1869(7)$ & $16.195(4)$ & $11.2878(3)$ \\
\hline $\mathrm{b}(\AA)$ & $12.2841(7)$ & 13.1519(11) & $13.0436(5)$ & $9.7711(13)$ & $14.8623(7)$ & $9.1869(7)$ & $12.987(3)$ & $11.2878(3)$ \\
\hline c $(\AA)$ & 23.3211(14) & $27.6119(19)$ & $20.3604(7)$ & $37.198(4)$ & 24.1499(11) & $19.476(3)$ & $12.289(3)$ & $22.2808(12)$ \\
\hline$\alpha\left({ }^{\circ}\right)$ & 90 & 90 & $108.352(1)$ & 90 & 91.598(1) & 90 & 90 & 90 \\
\hline$\beta\left({ }^{\circ}\right)$ & $107.761(1)$ & $114.188(2)$ & $103.547(1)$ & $138.248(3)$ & $102.758(1)$ & 90 & $97.082(5)$ & 90 \\
\hline$\gamma\left({ }^{\circ}\right)$ & 90 & 90 & $90.535(1)$ & 90 & $102.758(1)$ & 120 & 90 & 90 \\
\hline $\mathrm{V}\left(\AA^{3}\right)$ & $9908.8(10)$ & $12,323.7(18)$ & $2605.85(17)$ & $4584.7(10)$ & 4719.1(4) & $1423.5(3)$ & $2564.9(11)$ & $2838.9(2)$ \\
\hline $\mathrm{z}$ & 4 & 4 & 2 & 4 & 2 & 3 & 2 & 4 \\
\hline$\mu\left(\mathrm{cm}^{-1}\right)$ & 0.784 & 0.667 & 0.608 & 1.186 & 0.566 & 3.449 & 2.580 & 2.331 \\
\hline $\begin{array}{l}\text { No. of meas., indep. and } \\
\text { obs. refl. }\end{array}$ & $72,769,16,960,12,277$ & $57,468,14,880,11,554$ & $43,302,20,507,14,307$ & $48,895,12,935,6575$ & $41,719,18,266,13,442$ & $20,906,1595,1387$ & $18,259,4748,3764$ & $28,810,4927,3373$ \\
\hline $\begin{array}{c}R_{\text {int }} \\
R\left[F^{2}>2 \sigma\left(F^{2}\right)\right] w R\left(F^{2}\right) S\end{array}$ & $\begin{array}{c}0.0712 \\
0.0422 .0 .0944 .1 .004\end{array}$ & $\begin{array}{c}0.0595 \\
0.0425,0.1151,0.999\end{array}$ & $\begin{array}{l}0.0431 \\
0.0481 .01203\end{array}$ & $\begin{array}{c}0.1904 \\
0655\end{array}$ & $\begin{array}{c}0.0434 \\
0.041110 .0944,0.987\end{array}$ & $\begin{array}{l}0.1126 \\
0.343094\end{array}$ & $\begin{array}{c}0.0594 \\
0.039550 .1018,0.996\end{array}$ & $\begin{array}{l}0.0702 \\
0.04030055,098\end{array}$ \\
\hline $\begin{array}{c}R\left[F^{2}>2 \sigma\left(F^{2}\right)\right], w R\left(F^{2}\right), S \\
\Delta \rho_{\max } \Delta \rho_{\min }\left(\mathrm{e} \AA^{-3}\right)\end{array}$ & $\begin{array}{l}4.91,-0.33 \\
0.91,4004\end{array}$ & $\begin{array}{c}0.0425,0.1151,0.999 \\
2.45,-1.09\end{array}$ & $\begin{array}{c}0.0481,0.1203,1.006 \\
1.01,-0.52\end{array}$ & $\begin{array}{c}0.0655,0.0921,1.007 \\
0.98,-0.88\end{array}$ & $\begin{array}{c}0.0411,0.0944,0.987 \\
1.28,-0.57\end{array}$ & $\begin{array}{c}0.0343,0.0694,1.058 \\
0.79,-0.80\end{array}$ & $\begin{array}{c}0.0395,0.1018,0.996 \\
2.15,-1.51\end{array}$ & $\begin{array}{c}0.0403,0.0855,0.998 \\
0.75,-0.49\end{array}$ \\
\hline
\end{tabular}




\section{Results}

\subsection{Complexes with Non-Coordinated $\left[\mathrm{B}_{10} \mathrm{Cl}_{10}\right]^{2-}$ Anion}

A great number of mononuclear and binuclear silver complexes have been prepared where the unsubstituted $\left[\mathrm{B}_{10} \mathrm{H}_{10}\right]^{2-}$ anion was allowed to react with $\left[\mathrm{Ag}\left(\mathrm{Ph}_{3} \mathrm{P}\right)_{3} \mathrm{NO}_{3}\right]$ and a mixture of $\mathrm{AgNO}_{3}$ $+\mathrm{Ph}_{3} \mathrm{P}$ in organic media $[16,17]$. Taking this fact into consideration, the coordination ability of the perchlorinated anion was studied in the same conditions in the presence of $\mathrm{Ph}_{3} \mathrm{P}$.

First, the reaction between the $\left[\mathrm{B}_{10} \mathrm{Cl}_{10}\right]^{2-}$ anion, $\mathrm{AgNO}_{3}$, and a two-fold excess of $\mathrm{Ph}_{3} \mathrm{P}$ was studied. The reaction was found to proceed according to Scheme 1.

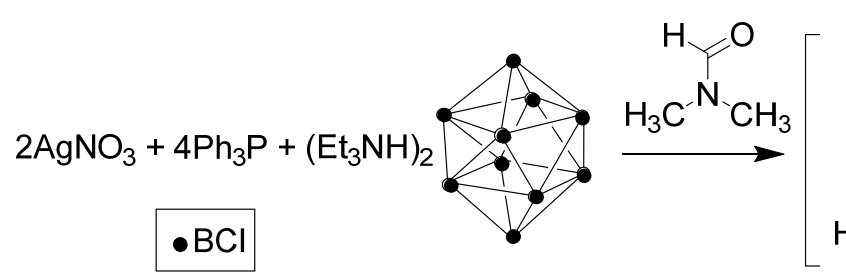

$\bullet \mathrm{BCl}$
$\mathrm{H}_{3} \mathrm{C}^{-\mathrm{N}}-\mathrm{CH}_{3}$<smiles>C[O+]=CN(C)C</smiles><smiles>CN(C)C(=O)O[Ge]P(=O)(P)P</smiles>

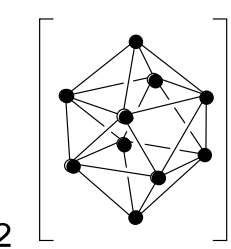

Scheme 1. Synthesis of complex 1.

The reaction proceeded in DMF which slowly evaporates at room temperature, and crystals $\left[\mathrm{Ag}\left(\mathrm{PPh}_{3}\right)_{2}(\mathrm{DMF})_{2}\right]_{2}\left[\mathrm{~B}_{10} \mathrm{Cl}_{10}\right] \cdot 2 \mathrm{DMF}(\mathbf{1} \cdot 2 \mathrm{DMF})$ precipitated directly from the reaction solution after a week of keeping the solution in air.

In this compound, the coordination sphere of silver is formed by $\mathrm{Ph}_{3} \mathrm{P}$ and DMF molecules (Figure 1). This cation has not been found in compounds containing the boron cluster anions before.

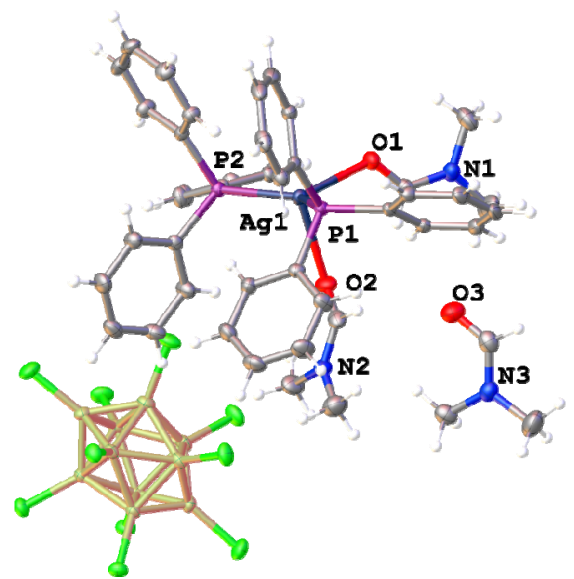

(a)
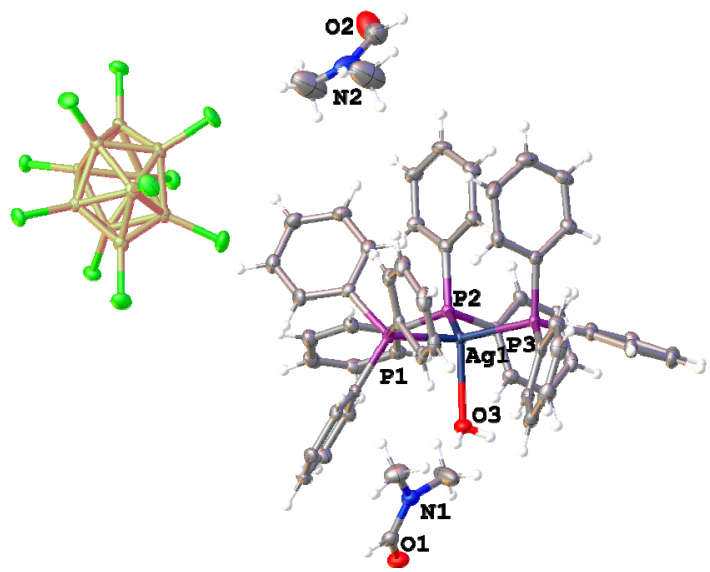

(b)

Figure 1. Molecular view of (a) complex 1 $2 \mathrm{DMF}$ and (b) $2 \cdot 4 \mathrm{DMF}$ in representation of atoms with thermal ellipsoids $(p=50 \%$ ). For both solids only half of the anion is symmetrically independent.

When previously prepared silver complex $\left[\mathrm{Ag}\left(\mathrm{Ph}_{3} \mathrm{P}\right)_{3} \mathrm{NO}_{3}\right]$ was used as the initial reagent, the reaction proceeded according to Scheme 2 and crystals $\left[\mathrm{Ag}\left(\mathrm{Ph}_{3} \mathrm{P}\right)_{3}\left(\mathrm{H}_{2} \mathrm{O}\right)\right]_{2}\left[\mathrm{~B}_{10} \mathrm{Cl}_{10}\right] \cdot 4 \mathrm{DMF}(2 \cdot 4 \mathrm{DMF})$ precipitated from the reaction mixture. 

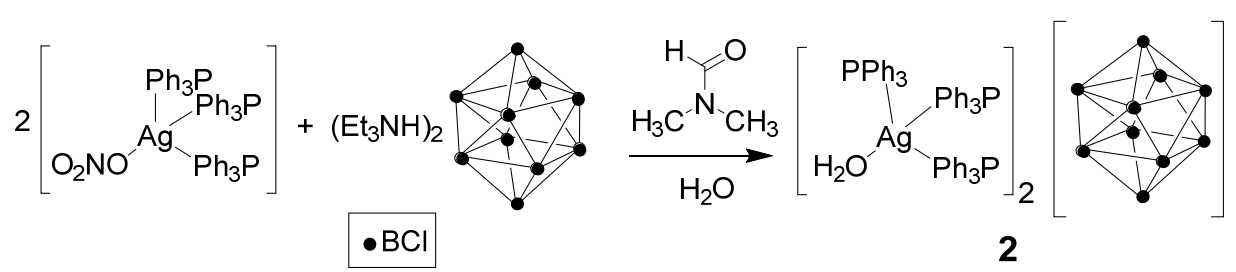

Scheme 2. Synthesis of complex 2.

In this case, the metathesis reaction proceeded in the coordination sphere of silver atom when the nitrate anion was replaced by $\mathrm{H}_{2} \mathrm{O}$ molecule while the number of coordinated $\mathrm{Ph} 3 \mathrm{P}$ ligands remained unchanged (Figure 1). It seems that the source of water molecules is air, because we use HPLC solvents; however, the reaction mixture was allowed to stand in air for a continuous time and some water vapor could dissolve in the reaction mixture.

It is known that the boron cluster anions form copper(I) complexes with $\mathrm{Ph}_{3} \mathrm{P}$ with a general formula $\left[\left(\mathrm{Ph}_{3} \mathrm{P}\right)_{4} \mathrm{Cu}_{2}\left[\mathrm{~B}_{n} \mathrm{H}_{n}\right]\right](\mathrm{n}=6,10,12)[42-46]$. Therefore, we attempted to obtain analogous compounds with copper(I) according to similar reactions using $\left[\mathrm{Cu}\left(\mathrm{Ph}_{3} \mathrm{P}\right)_{3} \mathrm{Cl}\right]$ and salts of the $\left[\mathrm{B}_{10} \mathrm{Cl}_{10}\right]^{2-}$ anion. However, when $\left[\mathrm{Cu}\left(\mathrm{Ph}_{3} \mathrm{P}\right)_{3} \mathrm{Cl}\right]$ was added to the reaction mixture containing $\left[\mathrm{B}_{10} \mathrm{Cl}_{10}\right]^{2-}$, copper(I) complexes with $\mathrm{Ph}_{3} \mathrm{P}$ and chloride anions $3 \cdot 2 \mathrm{DMF}$ and 4 precipitated (Scheme 3), with the $\left[\mathrm{B}_{10} \mathrm{Cl}_{10}\right]^{2-}$ salts being in the reaction solution.

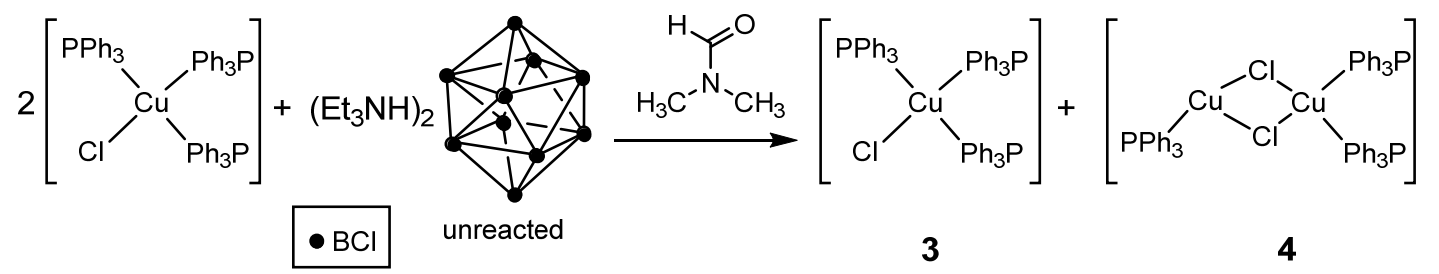

Scheme 3. Preparation of copper(I) compounds 3 and 4.

Both crystals 3 - 2DMF and 4 are colorless, precipitated together, and contain no boron cluster (Figure 2). Both compounds were characterized only by the X-ray single crystal diffraction; the elemental analysis could not be carried out because it is hardly possible to separate both types of crystals from the mixture in required amounts. Crystal structures of pure 3 and 4 as well as some of their solvates have previously been published [39,47-49]; none of these previous publications mentioned the cocrystallization of the monomer 3 and dimer 4 . The structure of $3 \cdot 2 \mathrm{DMF}$ is novel, and this crystal is isostructural with previously reported acetone solvate [39]. Crystal parameters of 4 do not coincide with those for the \{CTPPCU\} Refcode family in the Cambridge Structural Database (see, for example, \{CTPPCU03\} [47]) due to different space group settings, however theoretical powder XRD patterns indicate that these phases are identical (Figure S8, Supplementary Materials). The initial closo-decaborate salt remains in the solution and precipitates after about two weeks of standing in air.

The cation $\left[\mathrm{Ag}\left(\mathrm{Ph}_{3} \mathrm{P}\right)_{3}\left(\mathrm{H}_{2} \mathrm{O}\right)\right]^{+}$found in $2 \cdot 4 \mathrm{DMF}$ was earlier obtained in silver complexation reactions with the $\left[\mathrm{B}_{20} \mathrm{H}_{18}\right]^{2-}$ anion when using $\left[\mathrm{Ag}\left(\mathrm{Ph}_{3} \mathrm{P}\right)_{3} \mathrm{NO}_{3}\right]$ as the initial reagent to form $\left[\mathrm{Ag}\left(\mathrm{Ph}_{3} \mathrm{P}\right)_{4}\right]\left[\mathrm{Ag}\left(\mathrm{Ph}_{3} \mathrm{P}\right)_{3}\left(\mathrm{H}_{2} \mathrm{O}\right)\right]\left[\mathrm{B}_{20} \mathrm{H}_{18}\right][17,18]$. At the same time, for the paternal $\left[\mathrm{B}_{10} \mathrm{H}_{10}\right]^{2-}$ anion, the reaction between $\left[\mathrm{B}_{10} \mathrm{H}_{10}\right]^{2-}$ and $\left[\mathrm{Ag}\left(\mathrm{Ph}_{3} \mathrm{P}\right)_{3} \mathrm{NO}_{3}\right]$ has been studied only in $\mathrm{CH}_{3} \mathrm{CN}$ when a binuclear complex $\left[\mathrm{Ag}_{2}\left(\mathrm{Ph}_{3} \mathrm{P}\right)_{4}\left[\mathrm{~B}_{10} \mathrm{H}_{10}\right]\right]$ with the $\left[\mathrm{B}_{10} \mathrm{H}_{10}\right]^{2-}$ coordinated was obtained [16]. Thus, in order to study the silver complexation with $\left[\mathrm{B}_{10} \mathrm{H}_{10}\right]^{2-}$ and $\left[\mathrm{B}_{10} \mathrm{Cl}_{10}\right]^{2-}$ in similar conditions (in the same solvent), the silver complexation with the $\left[\mathrm{B}_{10} \mathrm{H}_{10}\right]^{2-}$ was performed in DMF instead of $\mathrm{CH}_{3} \mathrm{CN}$. It was found that the reaction results in $\left[\mathrm{Ag}\left(\mathrm{Ph}_{3} \mathrm{P}\right)_{4}\right]\left[\mathrm{Ag}\left(\mathrm{Ph}_{3} \mathrm{P}\right)_{2}\left[\mathrm{~B}_{10} \mathrm{H}_{10}\right]\right]$ (5) according to Scheme 4. This compound is isostructural with previously reported $\left[\mathrm{Ag}\left(\mathrm{Ph}_{4} \mathrm{P}\right)_{4}\right]\left[\mathrm{Ag}\left(\mathrm{Ph}_{3} \mathrm{P}\right)_{2}[\mathrm{An}]\right]$, where [An] are the $\left[\mathrm{B}_{10} \mathrm{H}_{10}\right]^{2-}$ and $\left[\mathrm{B}_{10} \mathrm{H}_{9} \mathrm{Cl}\right]^{2-}$ anions cocrystallized in the $50: 50$ ratio [17]. 


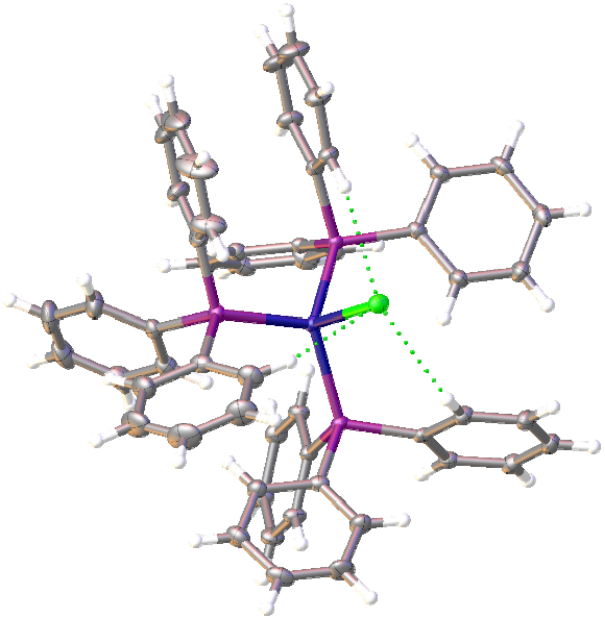

(a)

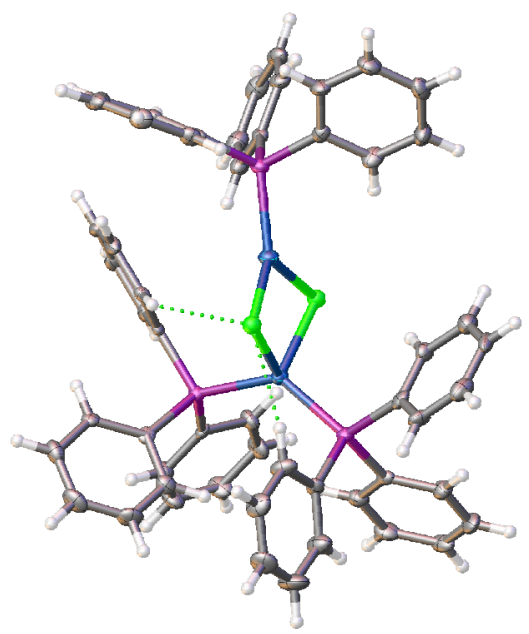

(b)

Figure 2. Molecular view of (a) 3 and (b) 4 in representation of atoms with thermal ellipsoids ( $p=50 \%$ ). Solvent molecules are omitted.

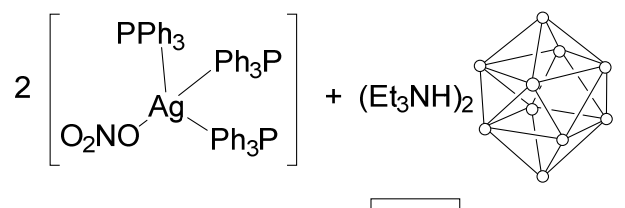

$\circ \mathrm{BH}$

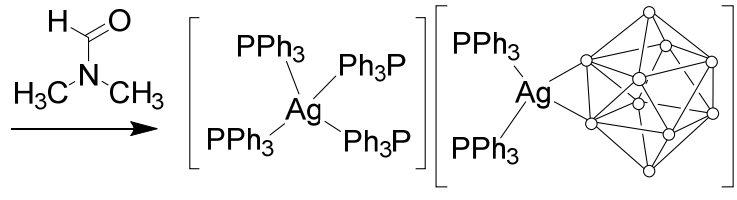

5

Scheme 4. Synthesis of complex 5.

In the IR spectra of compounds 1 - 2DMF and 2 - 4DMF, bands $v(\mathrm{BCl})$ (near $1155 \mathrm{~cm}^{-1}$ and $1000 \mathrm{~cm}^{-1}$ ) from the boron cluster and $v(\mathrm{CO})\left(\right.$ near $1660 \mathrm{~cm}^{-1}$ ) from DMF molecules are observed, as well as a set of bands in the region $1100-600 \mathrm{~cm}^{-1}$ corresponded to $\mathrm{Ph}_{3} \mathrm{P}$ coordinated by metal atom. In the IR spectrum of crystals $5 \cdot 0.1 \mathrm{H}_{2} \mathrm{O}$, bands $v(\mathrm{BH})$ and $v(\mathrm{BH})_{\mathrm{MHB}}$ corresponded to the $\mathrm{BH}$ groups free and coordinated by the metal atom, respectively, are observed in the region $2500-2200 \mathrm{~cm}^{-1}$. A weak band with a maximum near $1673 \mathrm{~cm}^{-1}$ is assigned to $v(C O)$ of solvent DMF molecules contained in freshly prepared crystals. Water molecule is not seen in the IR spectrum of crystals. In addition, a set of bands in the region 1100-600 $\mathrm{cm}^{-1}$ corresponded to $\mathrm{Ph}_{3} \mathrm{P}$ coordinated by metal atom is observed. As in the case of $2 \cdot 4 \mathrm{DMF}$, the source of water molecules seems to be air because of continuous standing of the reaction mixture in air.

Complexes 1-5 obtained from DMF at presence of $\mathrm{Ph}_{3} \mathrm{P}$ contain no coordinated $\left[\mathrm{B}_{10} \mathrm{Cl}_{10}\right]^{2-}$ anion. In complexes 1, 2, and $\mathbf{5}$ silver(I) is tetracoordinated (Figures 1 and 3). Coordination polyhedra ${ }^{\prime} g^{I} P_{2} \mathrm{O}_{2}$ (1 - 2DMF), $A g^{I} P_{3} \mathrm{O}(2 \cdot 4 \mathrm{DMF})$, and $A g^{I} P_{4}$ or $A g^{I} P_{2} H_{2}\left(5 \cdot 0.1 \mathrm{H}_{2} \mathrm{O}\right)$ possess tetrahedral geometry. Bond lengths $\mathrm{Ag}-\mathrm{P}$ increase from bis to tetrakis $\mathrm{Ph}_{3} \mathrm{P}$-substituted complexes due to steric hindrances (Table 2). The Ag-O bonds in 1 - 2DMF strongly deviate from each other (Table 2), although both correspond to interactions between a metal atom and a DMF molecule. Crystals of $\mathbf{1} \cdot 2 \mathrm{DMF}$ and $\mathbf{2} \cdot 4 \mathrm{DMF}$ contain also solvent DMF molecules, while $\mathbf{2} \cdot 4 \mathrm{DMF}$ and $\mathbf{5} \cdot 0.1 \mathrm{H}_{2} \mathrm{O}$ contain a coordinated and an uncoordinated water molecules, respectively. The $\left[\mathrm{B}_{10} \mathrm{Cl}_{10}\right]^{2-}$ anion in $\mathbf{1} \cdot 2 \mathrm{DMF}$ and $\mathbf{2} \cdot 4 \mathrm{DMF}$ acts as a counterion involved in numerous $\mathrm{C}-\mathrm{H} \ldots \mathrm{Cl}$ intermolecular interactions with hydrogen atoms of $\mathrm{Ph}$ and Me groups. The $\left[\mathrm{B}_{10} \mathrm{H}_{10}\right]^{2-}$ anion in $5 \cdot 0.1 \mathrm{H}_{2} \mathrm{O}$ is coordinated by silver(I) atom via one of equatorial edges. The same coordination accompanied with the anion disorder was observed in its' monochlorosubstituted isostructural analog [17]. Two disordered anions are coordinated via 2-6 or 2-9 edges of the boron polyhedral anion. One of two copper(I) atoms in 4 and that in 3 also exhibit tetrahedral geometry. Bond distances reflect the fact that copper(I) atom has smaller radius 
than silver(I). For both bis $(\mathbf{1}, \mathbf{4})$ and tris $(\mathbf{2}, \mathbf{3}) \mathrm{PPh}_{3}$-containing complexes, the $\mathrm{M}$-P bond distances are shorter in copper(I) complexes. The $\mathrm{Cu}(2)$ atom in $\mathbf{4}$ has the trigonal-planar coordination. Molecular geometries of 3 and 4 are very similar with previously published analogs [39,47-49]. Both the M-P and $\mathrm{M}-\mathrm{Cl}$ distances are the shortest among compounds under discussion for this atom.

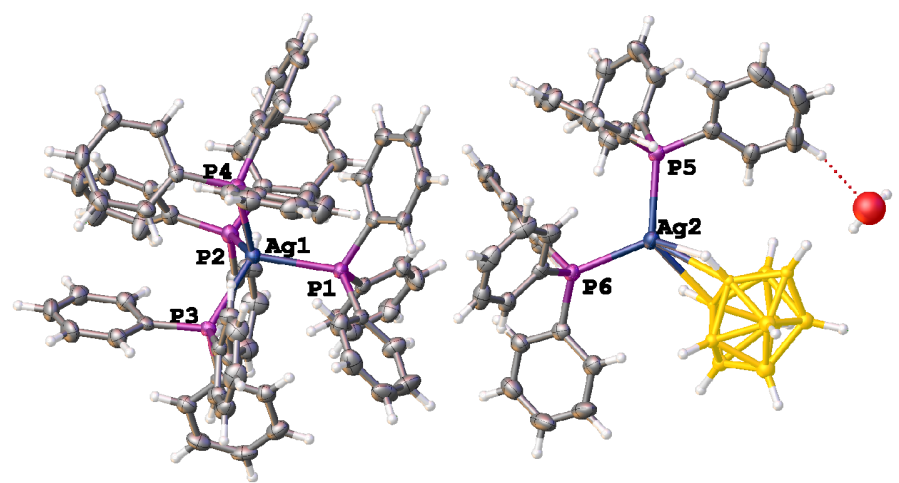

Figure 3. Molecular view of complex $5 \cdot 0.1 \mathrm{H}_{2} \mathrm{O}$ in representation of atoms with thermal ellipsoids $(p=50 \%)$. Only one of two positions of the disordered cage anion is depicted.

Table 2. Selected geometrical parameters $(\AA)$ of coordination polyhedra of 1-5.

\begin{tabular}{|c|c|c|c|c|c|}
\hline Bond & $1 \cdot 2 \mathrm{DMF}$ & $2 \cdot 4 \mathrm{DMF}$ & $3 \cdot 2 \mathrm{DMF}$ & 4 & $5 \cdot 0.1 \mathrm{H}_{2} \mathrm{O}$ \\
\hline M & $\mathrm{Ag}^{\mathrm{I}}$ & $\mathrm{Ag}^{\mathrm{I}}$ & $\mathrm{Cu}^{\mathrm{I}}$ & $\mathrm{Cu}^{\mathrm{I}}$ & $\mathrm{Ag}^{\mathrm{I}}$ \\
\hline $\mathrm{M}-\mathrm{P}$ & $2.4174(5)-2.4262(5)$ & $2.4873(7)-2.4967(7)$ & $2.3125(5)-2.3197(4)$ & $2.177(1)-2.236(1)$ & $2.4921(8)-2.6516(8)$ \\
\hline $\mathrm{M}-\mathrm{O}$ & $2.374(2)-2.536(2)$ & $2.476(2)$ & & & \\
\hline M...B & & & & & $2.646(6)-2.758(6)$ \\
\hline $\mathrm{M}-\mathrm{Cl}$ & & & $2.3358(4)$ & $2.245(1)-2.452(1)$ & \\
\hline
\end{tabular}

The obtained data allow us to compare the coordination ability of the three boron clusters in silver(I) complexation at presence of $\mathrm{Ph}_{3} \mathrm{P}$ as the following: $\left[\mathrm{B}_{10} \mathrm{H}_{10}\right]^{2-}>\left[\mathrm{B}_{20} \mathrm{H}_{18}\right]^{2-}>\left[\mathrm{B}_{10} \mathrm{Cl}_{10}\right]^{2-}$. This conclusion is made based on the fact that no silver(I) complexes with uncoordinated $\left[\mathrm{B}_{10} \mathrm{H}_{10}\right]^{2-}$ can be found among numerous silver(I) complexes with $\mathrm{Ph}_{3} \mathrm{P}$ known to date (polymeric, isomers of mononuclear silver complexes, isomers of dinuclear silver complexes); for $\left[\mathrm{B}_{20} \mathrm{H}_{18}\right]^{2-}$, complexes with coordinated and non-coordinated eicosaborate anion can be formed depending on the reagent ratio; as for the perchlorinated anion, only compounds with outer-sphere boron cluster have been isolated. The obtained data indicate also that it is more favorable for copper(I) to form neutral mononuclear or binuclear complex with $\mathrm{Ph}_{3} \mathrm{P}$ and $\mathrm{Cl}$ rather than a cationic copper(I) complex with the $\left[\mathrm{B}_{10} \mathrm{Cl}_{10}\right]^{2-}$ anion as counterion. It seems that the $\mathrm{Cu}-\mathrm{Cl}$ bonds are not favorable to be formed with the perchlorinated closo-decaborate anion, at least in the conditions studied here, thus further studies were carried out only for silver(I) atoms.

\subsection{Silver Complexes with Coordinated $\left[\mathrm{B}_{10} \mathrm{Cl}_{10}\right]^{2-}$ Anion}

It is known that the secondary $\mathrm{Ag}$... Hal bonds are found in a number of halogenated carboranes [28-35]; thus, to synthesize silver(I) complexes with the coordinated $\left[\mathrm{B}_{10} \mathrm{Cl}_{10}\right]^{2-}$ anion, a series of complexation reactions was carried out in the absence of organic ligands. $\mathrm{AgNO}_{3}$ and salts of $\left[\mathrm{B}_{10} \mathrm{Cl}_{10}\right]^{2-}$ were used as the reagents.

\subsubsection{Synthesis in Water}

First, the complexation reaction between $\left(\mathrm{Et}_{3} \mathrm{NH}\right)_{2}\left[\mathrm{~B}_{10} \mathrm{Cl}_{10}\right]$ and $\mathrm{AgNO} \mathrm{O}_{3}$ was performed in water. By the same approach $\left[\mathrm{Ag}_{2}\left[\mathrm{~B}_{10} \mathrm{H}_{10}\right]\right]_{n}$ was previously obtained $[50,51]$ in a quantitative yield immediately after fusing aqueous solutions of $\left(\mathrm{Et}_{3} \mathrm{NH}\right)_{2}\left[\mathrm{~B}_{10} \mathrm{H}_{10}\right]$ and $\mathrm{AgNO}_{3}$ taken in the 1:2 molar 
ratio. $\left[\mathrm{Ag}_{2}\left[\mathrm{~B}_{10} \mathrm{H}_{10}\right]\right]_{n}$ precipitates as white powder and its $3 \mathrm{D}$ framework structure was succeeded to be determined by in situ synchrotron radiation powder $\mathrm{X}$-ray diffraction [52]. However, when aqueous solutions of $\left(\mathrm{Et}_{3} \mathrm{NH}\right)_{2}\left[\mathrm{~B}_{10} \mathrm{Cl}_{10}\right]$ and $\mathrm{AgNO}_{3}$ (in the 1:2 molar ratio) were poured in one beaker, no precipitate was observed. After continuous standing of the reaction mixture in air at room temperature, when water is almost evaporated, single crystals of $\left[\mathrm{Ag}_{2}\left[\mathrm{~B}_{10} \mathrm{Cl}_{10}\right]\right]_{n}$ (6) formed (Scheme 5).

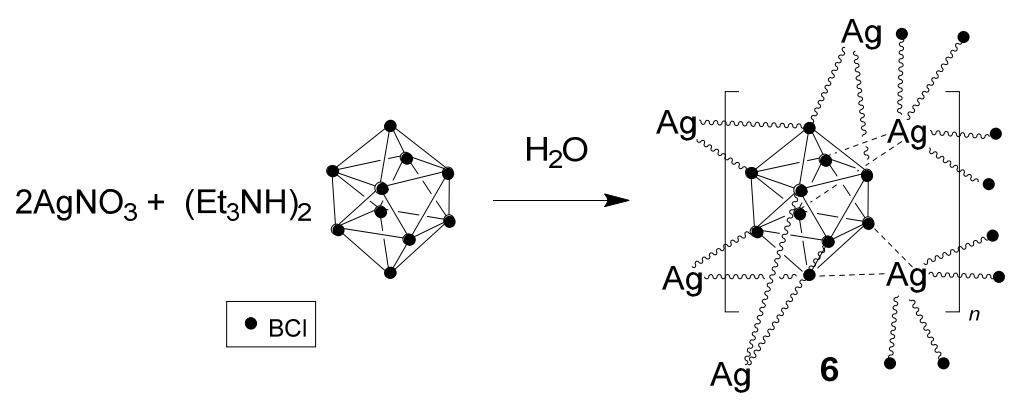

Scheme 5. Synthesis of complex 6.

Note that the reaction mixture becomes black because of partial reduction of silver to form $\mathrm{Ag}^{0}$; in the above experiments. The presence of $\mathrm{Ph}_{3} \mathrm{P}$ stabilized $\mathrm{Ag}^{+}$in the reaction mixture (complexes 1 - 2DMF and 2 - 4DMF were prepared in air at daylight conditions, the reaction mixtures remained colorless and transparent and no black or grey color was observed).

Molecular structure of complex 6 and the environment of both ions are depicted in Figure 4a. The cation coordinates three anions in a chelate mode through five-membered $\mathrm{Cl}-\mathrm{B}-\mathrm{B}-\mathrm{Cl}-\mathrm{Ag}$ rings to form an $\mathrm{AgCl}_{6}$ octahedron with bond distances varying from 2.706(1) to 2.893(1) $\AA$ (Table 3). Each anion interacts with six cations. Four of them coordinate one apical and one equatorial chlorine atom, and two silver atoms interact with two equatorial chlorine atoms (Figure $4 \mathrm{~b}$ ). The resulting 3D network contains isolated pores (see Figure S12), but no residual electron density was found in these regions. Note that in $\left[\mathrm{Ag}_{2}\left[\mathrm{~B}_{12} \mathrm{Cl}_{12}\right]\right]_{n}[34]$, similar octahedral coordination of cations was found, and each anion bridges six cations, but total connectivity of 3D networks is different. Simplification of 3D frameworks of $\left[\mathrm{Ag}_{2}\left[\mathrm{~B}_{10} \mathrm{Cl}_{10}\right]\right]_{n}$ and $\left[\mathrm{Ag}_{2}\left[\mathrm{~B}_{12} \mathrm{Cl}_{12}\right]\right]_{n}$ results to 3,6-connected underlying nets (3-connected silver atoms and 6-connected anions) with topology of hexagonal anatase and pyrite.

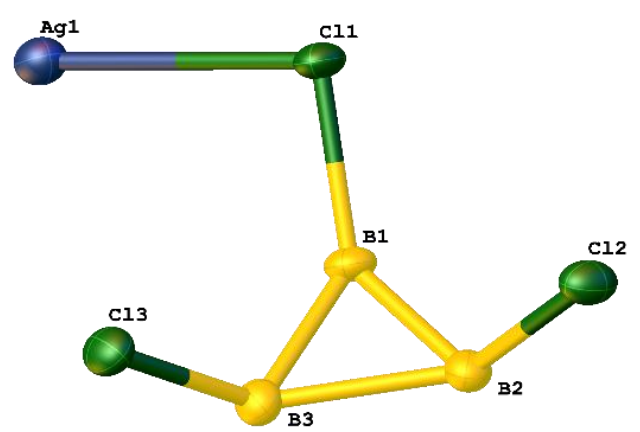

(a)

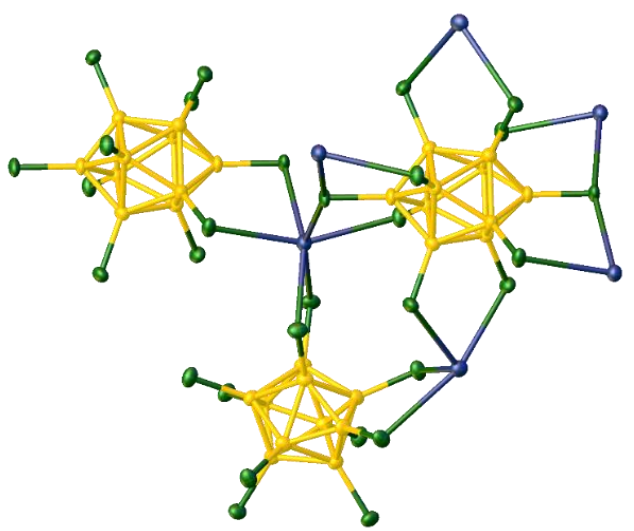

(b)

Figure 4. (a) Asymmetric unit of $\mathbf{6}$ and (b) closest environment of ions in representation of atoms with thermal ellipsoids ( $p=50 \%$ ). 
Table 3. Selected parameters ( $\AA$ ) of silver(I) coordination polyhedra in complexes with some chlorinated boron cages.

\begin{tabular}{|c|c|c|c|c|}
\hline Complex & $\mathrm{M}-\mathrm{Cl}$ & $\mathbf{M}-\mathbf{N}$ & $\mathbf{M}-\mathbf{O}$ & Reference \\
\hline 6 & $2.706(1)-2.893(1)$ & & & This work \\
\hline 7 & $2.6364(9)-3.4908(8)$ & & $2.391(2)$ & This work \\
\hline 8 & $3.000(1)-3.619(1)$ & $2.158(6)-2.159(6)$ & & This work \\
\hline$\left[\mathrm{Ag}_{2}\left[\mathrm{~B}_{12} \mathrm{Cl}_{12}\right]\right]_{n}$ & $2.825(2)-2.851(2)$ & & & [31] \\
\hline$\left[\mathrm{Ag}\left(\mathrm{CH}_{3} \mathrm{CN}\right)\left[\left(\mathrm{Me}_{3} \mathrm{~N}\right) \mathrm{B}_{12} \mathrm{Cl}_{11}\right]\right]_{n}$ & $2.652(1)-3.016(1)$ & $2.188(3)-2.227(3)$ & & [28] \\
\hline$\left\{\begin{array}{c}{\left[\mathrm{Ag}_{2}\left(\mathrm{SO}_{2}\right)\left[\left(\mathrm{Me}_{3} \mathrm{~N}\right) \mathrm{B}_{12} \mathrm{Cl}_{11}\right]_{2}\right]} \\
\left.\mathrm{SO}_{2}\right\}_{n}\end{array}\right.$ & $2.652(1)-2.899(1)$ & & $2.523(4)$ & [32] \\
\hline $\begin{array}{c}\left\{\left[\mathrm{Ag}\left[\left(\mathrm{Me}_{3} \mathrm{~N}\right) \mathrm{B}_{12} \mathrm{Cl}_{11}\right]\right]\right. \\
\left.0.5 \mathrm{CH}_{2} \mathrm{Cl}_{2}\right\}_{n}\end{array}$ & $2.668(2)-2.957(1)$ & & & [32] \\
\hline
\end{tabular}

The preparation of solvent-free crystals containing $\left[\mathrm{B}_{10} \mathrm{Cl}_{10}\right]^{2-}$ anion is a rare case, because this anion tends to form numerous secondary interactions with solvent molecules containing in the structures. This is the only structure besides $\left[\mathrm{Ag}\left(\mathrm{NH}_{3}\right)_{2}\right]_{2}\left[\mathrm{~B}_{10} \mathrm{Cl}_{10}\right]$ [26] that contains no solvent molecules. It seems that the coordination capacity of the boron cluster in $\mathbf{6}$ is spent to form numerous $\mathrm{Ag}-\mathrm{Cl}$ bonds, which resulted in isolation of solvent-free crystals.

\subsubsection{Synthesis in DMF}

When $\mathrm{AgNO}_{3}$ was allowed to react with $\left(\mathrm{Et}_{3} \mathrm{NH}\right)_{2}\left[\mathrm{~B}_{10} \mathrm{Cl}_{10}\right]$ in DMF, the reaction mixture became black because of partial silver reduction to $\mathrm{Ag}^{0}$. Grey crystals of target complex $\left[\mathrm{Ag}_{2}(\mathrm{DMF})_{2}\left[\mathrm{~B}_{10} \mathrm{Cl}_{10}\right]\right]_{n}$ (7) precipitated from the reaction solution (Scheme 6).

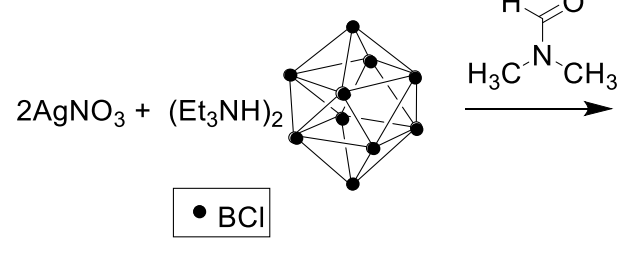

Scheme 6. Synthesis of complex 7.

Asymmetric unit of 7 contains a silver(I) ion, a DMF molecule, and half an anion (Figure 5a). DMF acts as a bridge ligand, and the anion is bridge-chelate octadentate. While $\mathrm{Ag}-\mathrm{O}_{\mathrm{DMF}}$ distances in $\mathbf{1}$ are comparable with the shortest $\mathrm{Ag}-\mathrm{O}_{\mathrm{DMF}}$ distance in 7 , the $\mathrm{Ag}-\mathrm{Cl}$ bonds vary in a wide range from 2.6364(9) to 3.4908(8) $\AA$ (Table 3). Besides, the Ag-Ag bond seems to be present in the complex as short as 3.2023(8) A. Eight chlorine atoms of the 10-vertex anion participate in coordination with four silver(I) atoms. Two cations interact with the anion through the cage edges including one apical and two equatorial atoms, and two others form six-membered Ag1-Ag1-Cl3-B3-B3-Cl3 rings. The presence of bridge DMF molecules and anions results in formation of infinite chains of complex 7 parallel with the crystallographic axis $c$ (Figure $5 b$ ).

Note that when studying the analogous silver(I) complexation reaction in the presence of the $\left[\mathrm{B}_{10} \mathrm{H}_{10}\right]^{2-}$ anion, polymeric complex $\left[\mathrm{Ag}_{2}(\mathrm{DMF})\left[\mathrm{B}_{10} \mathrm{H}_{10}\right]\right]_{n}[53]$ was obtained having a $3 \mathrm{D}$ framework structure (containing no $\mathrm{Ag}-\mathrm{Ag}$ bonds); eight $\mathrm{BH}$ groups form the $\mathrm{AgHB}$ bonds with the complexing agent. 


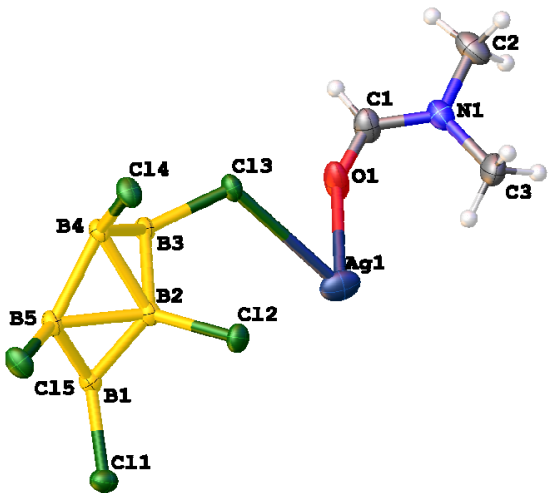

(a)

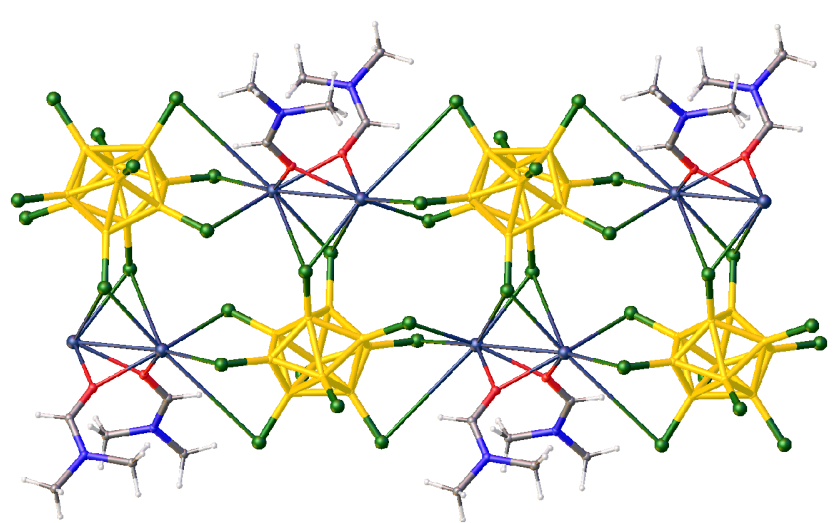

(b)

Figure 5. (a) Asymmetric unit of 7 in representation of atoms with thermal ellipsoids $(p=50 \%)$ and (b) fragment of infinite chains in crystal structure of 7.

It is interesting to note that because of high solubility of compound $\mathbf{7}$ (as well as it was noted for $\mathbf{6}$ ), crystals 7 precipitated only when the reaction solution was almost evaporated. Moreover, when the same reaction with $\mathrm{AgNO}_{3}$ was performed using $\mathrm{K}_{2}\left[\mathrm{~B}_{10} \mathrm{Cl}_{10}\right]$ instead of $\left(\mathrm{Et}_{3} \mathrm{NH}\right)_{2}\left[\mathrm{~B}_{10} \mathrm{Cl}_{10}\right]$, colorless crystals were formed after $24 \mathrm{~h}$ on the surface of the reaction mixture, but the cell parameters coincided with those reported for $\mathrm{K}_{2}\left[\mathrm{~B}_{10} \mathrm{Cl}_{10}\right] \cdot \mathrm{DMF} \cdot 2 \mathrm{H}_{2} \mathrm{O}$ [54]. High solubility of decachloro-closo-decaboratodisilver(I) in DMF resulted in precipitation of initial reagent $\mathrm{K}_{2}\left[\mathrm{~B}_{10} \mathrm{Cl}_{10}\right]$ with lower solubility; therefore, the target complex cannot be prepared from potassium salts. The starting compounds should be selected accurately when dealing with the $\left[\mathrm{B}_{10} \mathrm{Cl}_{10}\right]^{2-}$ anion, whereas for the paternal $\left[\mathrm{B}_{10} \mathrm{H}_{10}\right]^{2-}$ anion, the nature of the starting cation has no effect on the reaction affording $\left[\mathrm{Ag}_{2}\left[\mathrm{~B}_{10} \mathrm{H}_{10}\right]\right]$ to precipitate immediately when $\mathrm{Cat}_{2}\left[\mathrm{~B}_{10} \mathrm{H}_{10}\right](1 \mathrm{~mol})$ was allowed to react with $\mathrm{AgNO}_{3}(2 \mathrm{~mol})$ when using Cat $=\mathrm{Na}^{+}, \mathrm{K}^{+}, \mathrm{Cs}^{+}, \mathrm{R}_{4-n} \mathrm{NH}_{n}{ }^{+}(\mathrm{R}=\mathrm{Me}, \mathrm{Et}, \mathrm{Pr}, \mathrm{Bu}), \mathrm{Ph}_{4} \mathrm{P}^{+}, \mathrm{As}_{4} \mathrm{P}^{+}[51]$.

\subsubsection{Synthesis in Acetonitrile}

Finally, the silver(I) complexation were performed in acetonitrile. Knowing that $\mathrm{KNO}_{3}$ remains unsolved in acetonitrile, we use potassium salt $\mathrm{K}_{2}\left[\mathrm{~B}_{10} \mathrm{Cl}_{10}\right]$ to avoid the presence of foreign ions in the reaction solution. Indeed, when a solution of $\mathrm{AgNO}_{3}$ was added to a solution of $\mathrm{K}_{2}\left[\mathrm{~B}_{10} \mathrm{Cl}_{10}\right]$ in the same solvent, $\mathrm{KNO}_{3}$ precipitated almost quantitatively which was filtered off. White precipitate $\left[\mathrm{Ag}_{2}(\mathrm{MeCN})_{2}\left[\mathrm{~B}_{10} \mathrm{Cl}_{10}\right]\right]_{h}(8)$ was formed in the mother solution after $24 \mathrm{~h}$ (Scheme 7).

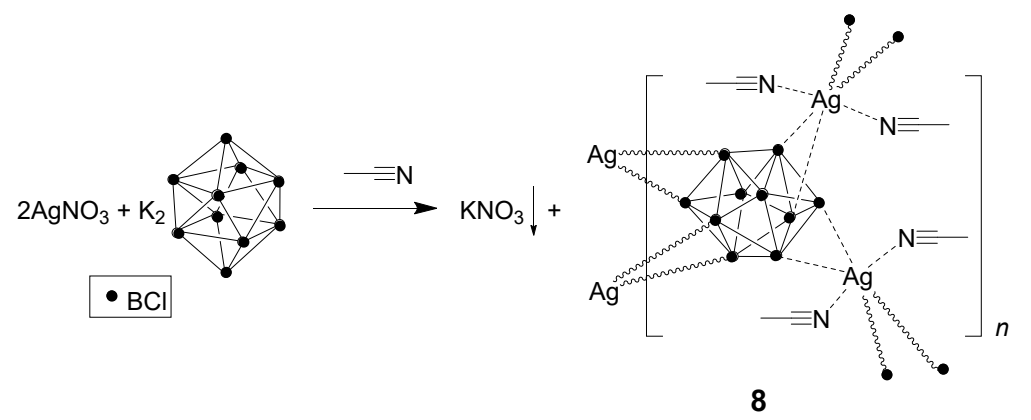

Scheme 7. Synthesis of complex 8.

The effect of a complexing agent on the coordination ability of the perchorinated boron cage can additionally be demonstrated on the example of $\left[\mathrm{Ag}_{2}(\mathrm{MeCN})_{2}\left[\mathrm{~B}_{10} \mathrm{Cl}_{10}\right]\right]_{n}(8)$. Its asymmetric unit is depicted on Figure 6a. Silver atom also coordinates two solvent molecules and two anions to form an $\mathrm{AgN}_{2} \mathrm{Cl}_{4}$ coordination polyhedron, but acetonitrile is a stronger donor of the electron density; thus, the $\mathrm{Ag}-\mathrm{N}$ coordination bonds in 8 are shorter than the $\mathrm{Ag}-\mathrm{O}$ bonds in 7 , while the $\mathrm{Ag}-\mathrm{Cl}$ bonds are 
elongated despite less steric hindrances from acetonitrile. Each anion is involved in bonding with four metal atoms; as a result, a 3D network occurs as depicted on Figure $6 \mathrm{~b}$.

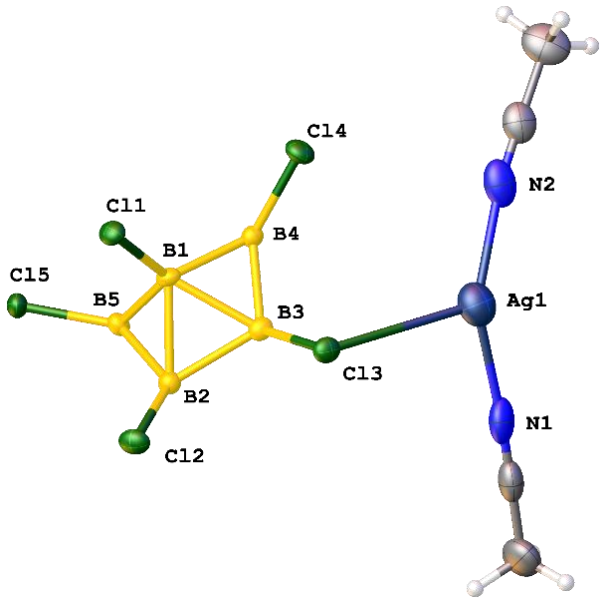

(a)

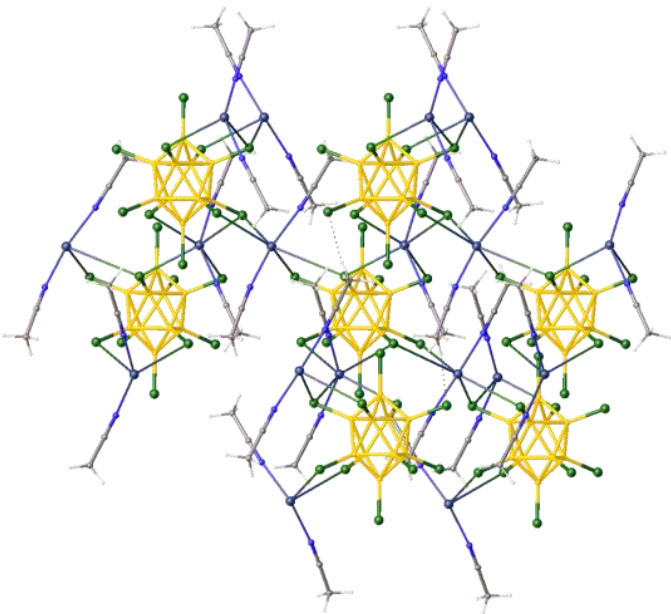

(b)

Figure 6. (a) Asymmetric unit of 8 in representation of atoms with thermal ellipsoids $(p=50 \%)$ and (b) fragment of crystal packing of 8 .

In the IR spectra of compound 6, only bands $v(\mathrm{BCl})$ are present. The bands are observed at the same regions as in salts $\mathrm{K}_{2}\left[\mathrm{~B}_{10} \mathrm{Cl}_{10}\right]$ and $\left(\mathrm{Et}_{3} \mathrm{NH}\right)_{2}\left[\mathrm{~B}_{10} \mathrm{Cl}_{10}\right]$. Therefore, we are unable to discuss the structure of compound $\mathbf{6}$ based in IR spectra only. In the IR spectrum of compound $8, v(\mathrm{C} \equiv N)$ corresponding to acetonitrile molecules and $v(\mathrm{BCl})$ bands are observed. In the Raman spectrum of 7 there are bands at 308 and $281 \mathrm{~cm}^{-1}$ which could be assigned to $v(\mathrm{BCl})$ and $v(\mathrm{AgCl})$, respectively, analogously with the spectrum of compound 4 . Besides $v(\mathrm{BCl})$ bands, the spectra of 7 contain the $v(\mathrm{CO})$ band corresponding to DMF molecules. In the Raman spectrum of 6 (see Figure S4), a strong band at $309 \mathrm{~cm}^{-1}$ is observed, which corresponds to $v(\mathrm{BCl})$ as it was assigned in ref. [55] for $\left[\mathrm{B}_{10} \mathrm{Cl}_{10}\right]^{2-}$ anion; a band at $281 \mathrm{~cm}^{-1}$ can be attributed to $v(\mathrm{AgCl})$ based on data indicated for $\mathrm{AgCl}$ [56]. In the Raman spectrum of $8, v(\mathrm{BCl})$ and $v(\mathrm{AgCl})$ bands are observed similarly to the Raman spectra of compounds 4 and 5 .

Summarizing the results obtained for silver complexation, we can confirm that both $\left[\mathrm{B}_{10} \mathrm{H}_{10}\right]^{2-}$ anion and its perchlorinated analog form coordination bonds with silver atom, but $\left[\mathrm{B}_{10} \mathrm{Cl}_{10}\right]^{2-}$ needs strict conditions to form inner-sphere complexes. First, no competing ligands and cations should be present; second, the tendency of the $\left[\mathrm{B}_{10} \mathrm{Cl}_{10}\right]^{2-}$ anion to form numerous $\mathrm{Cl} \ldots \mathrm{X}$ and $\mathrm{Cl} \ldots \mathrm{H}-\mathrm{X}$ interactions $(X=C, N, O)$ with organic cations, ligands, and solvent molecules should be taken into account. This type of interactions can be assumed based on the X-ray diffraction data and are confirmed by ${ }^{35} \mathrm{ClNQR}$ spectroscopic studies for a number of salts and complexes $[23,26,54,57]$. These interactions can result in a solvent shell appeared around the $\left[\mathrm{B}_{10} \mathrm{Cl}_{10}\right]^{2-}$ anion in solution, which prevent it from forming direct contacts with metals and can be a reason for high solubility of its compounds. All three complexes are the first representatives of the coordinated $\left[\mathrm{B}_{10} \mathrm{Cl}_{10}\right]^{2-}$ anion that demonstrate inclination of the anion to form five-membered $\mathrm{Cl}-\mathrm{B}-\mathrm{B}-\mathrm{Cl}-\mathrm{Ag}$ rings via various coordination modes. High distortion of coordination polyhedra and prominent variation of $\mathrm{Ag} \ldots \mathrm{Cl}$ bond distances makes it difficult to propose a coordination mode of the anion and coordination environment of the silver(I) atom. In this case, other approaches besides interatomic distances such as the atomic Hirshfeld surface can be very helpful. 


\subsection{The Hirshfeld Analysis of Ag ... Cl-B Bonding}

The atomic Hirshfeld surfaces (sAHS) proved themselves to be an easy and valuable tool for analysis of chemical bonding including multicentered one between metal atoms and boron cages $[18,58,59]$. Besides, the AHS can be used to compare chemical bonding for a series of similar compounds [60,61]. The curvedness plotted on the AHS allows visualization of the degree of covalency for a given bond. Red regions (flat surface) are associated with covalent bonding position, and green-blue denotes ionic bonding [62-64]. CrystalExplorer 17.5 [65] was used to obtain AHS of copper(I) atoms in 4, silver(I) atoms for 5-8 and some chlorinated dodeca(car)boranes.

Visual difference between $\mathrm{Ag}-\mathrm{H}-\mathrm{B}$ and $\mathrm{Ag}$... Cl-B is demonstrated on Figure 7. The former bonds are more sphere-like, and boron atoms take part in this bonding that manifests itself through corresponding green regions on the atomic Hirshfeld surface mapped with curvedness (ranged from -1.4 to -0.3$)$. The latter bonds are all flat that is typical for covalent bonds. Even $\mathrm{Ag}-\mathrm{O}$ and $\mathrm{Ag}-\mathrm{N}$ bonds between silver(I) atoms and solvent molecules demonstrate more prominent curvedness. The majority of coordination polyhedra of silver(I) atoms are much distorted, and $\mathrm{Ag}-\mathrm{Cl}$ bonds vary in a large range from 2.652(1) to 3.619(1) $\AA$, thus the AHS become a convenient method to distinguish various coordination isomers of boron cages. Using this approach, it is easy to conclude that $\left[\mathrm{B}_{10} \mathrm{Cl}_{10}\right]^{2-}$ and $\left[\mathrm{B}_{12} \mathrm{Cl}_{12}\right]^{2-}$ anions in respectively $\left[\mathrm{Ag}_{2}\left[\mathrm{~B}_{10} \mathrm{Cl}_{10}\right]\right]_{n}(\mathbf{6})$ or $\left[\mathrm{Ag}_{2}(\mathrm{MeCN})_{2}\left[\mathrm{~B}_{10} \mathrm{Cl}_{10}\right]\right]_{n}(8)$ and $\left[\mathrm{Ag}_{2}\left[\mathrm{~B}_{12} \mathrm{Cl}_{12}\right]\right]_{n}[34]$ are both coordinated through their edges, while in crystals of $(7),\left[\mathrm{Ag}\left(\mathrm{CH}_{3} \mathrm{CN}\right)\left[\left(\mathrm{Me}_{3} \mathrm{~N}\right) \mathrm{B}_{12} \mathrm{Cl}_{11}\right]\right]_{n}[28]$, $\left\{\left[\mathrm{Ag}_{2}\left(\mathrm{SO}_{2}\right)\left[\left(\mathrm{Me}_{3} \mathrm{~N}\right) \mathrm{B}_{12} \mathrm{Cl}_{11}\right]_{2}\right] \cdot \mathrm{SO}_{2}\right\}_{n}$ [32] and $\left\{\left[\mathrm{Ag}\left[\left(\mathrm{Me}_{3} \mathrm{~N}\right) \mathrm{B}_{12} \mathrm{Cl}_{11}\right]\right] \cdot 0.5 \mathrm{CH}_{2} \mathrm{Cl}_{2}\right\}_{n}$ [32] the coordination through boron faces and vertices was found. Although $\mathrm{Ag}-\mathrm{Cl}$ bonds for these four complexes are in the same range, and dodecaboron cages are larger than decaboron one, the faces of an AHS corresponding to all three $\mathrm{Ag}-\mathrm{Cl}$ bonds with a face of a chlorinated dodecaboron anion are similar, and those corresponding to the bonds with the $\left[\mathrm{B}_{10} \mathrm{Cl}_{10}\right]^{2-}$ anion in 7 are not equivalent. This fact may be indicative of lower coordination ability of $\left[\mathrm{B}_{10} \mathrm{Cl}_{10}\right]^{2-}$ than $\left[\mathrm{RB}_{12} \mathrm{Cl}_{11}\right]^{-}$or of non-equivalence of apical and equatorial atoms in the former anion. Non-equivalence of AHS faces of silver atoms and the lengths of $\mathrm{Ag}-\mathrm{Cl}$ bonds in $\left[\mathrm{Ag}_{2}\left[\mathrm{~B}_{10} \mathrm{Cl}_{10}\right]\right]_{n}(\mathbf{6})$ as compared with $\left[\mathrm{Ag}_{2}\left[\mathrm{~B}_{12} \mathrm{Cl}_{12}\right]\right]_{n}$ support the second assumption. It is known that the apical vertices of the $\left[\mathrm{B}_{10} \mathrm{H}_{10}\right]^{2-}$ anion are more negatively charged and are more inclined to take part in MHB bonding. The same is observed for compounds 6-8, where all apical chlorine atoms are involved in $\mathrm{Ag}-\mathrm{Cl}$ bonding (Figure 8). The $\left[\mathrm{B}_{10} \mathrm{Cl}_{10}\right]^{2-}$ anion takes part in bonding with up to six silver(I) atoms that is unusual for the smaller $\left[\mathrm{B}_{10} \mathrm{H}_{10}\right]^{2-}$ analog. All three anions have different coordination.

In (7), the AHS indicates presence of an Ag-Ag bond (Figure 7d). The AHSs of two metal atoms share a face that is associated with the concentration of charge density. The spectroscopic evidence of the presence of the Ag-Ag bond can be provided from the Raman spectrum of complex 7 (Figure S5): a peak with a maximum at $185 \mathrm{~cm}^{-1}$ can be attributed to the $\mathrm{Ag}-\mathrm{Ag}$ bond analogously with the data presented in [66] for $\mathrm{Ag}_{4}{ }^{+}$; note that in the Raman spectra of $\left\{\mathrm{Ag}_{2}\left[\mathrm{~B}_{10} \mathrm{Cl}_{10}\right]\right\}_{n}$ (6) this band in absent. For comparison, metal atoms in the copper-containing dimer 4 do not share any AHS face (Figure 7a), although the distance between these atoms is shorter than between silver(I) atoms in 7 (2.900(1) $\AA$ as compared with 3.2022(9) $\AA$ ). This Cu .. C Cu distance is similar with the distance observed in complex 4 crystallized from other polar solvents [47] while crystallization from non-polar media results in elongation of $\mathrm{Cu}$... Cu bonds. Previously reported DFT calculations of 4 demonstrated stabilization of this dimer due to delocalization of electron density along the four-membered ring [47].

Thus, the atomic Hirshfeld surfaces of metal atoms in silver(I) complexes with coordinated decachloro-closo-decaborate anions indicate covalent character of $\mathrm{Ag}-\mathrm{Cl}$ bonding. This approach allows revealing metal-metal bonding and the coordination mode of cage anions. The anions are prone to form numerous $\mathrm{Ag}-\mathrm{Cl}$ bonds through the cage edges and faces; and apical chlorine atoms more readily form $\mathrm{Ag}-\mathrm{Cl}$ bonds. 


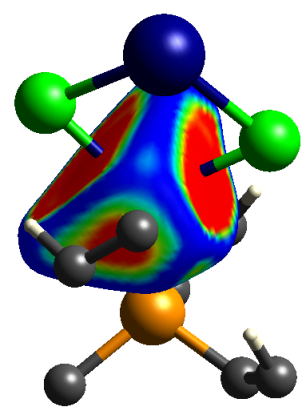

(a)

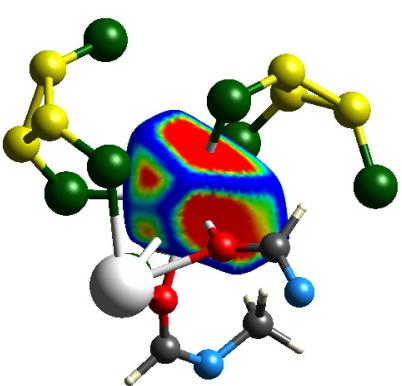

(d)

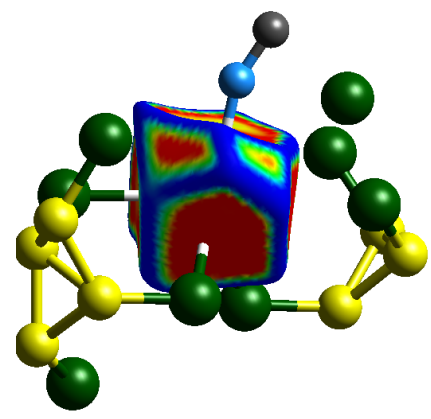

(g)

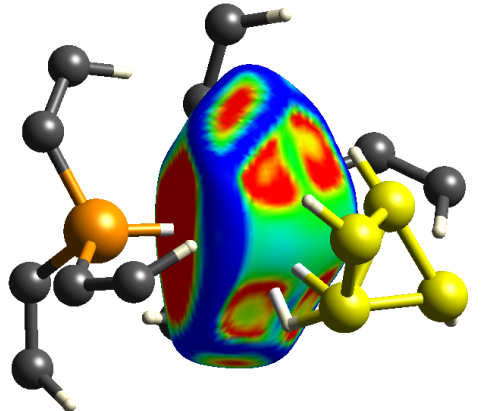

(b)

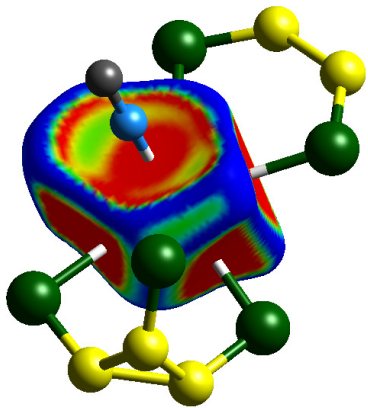

(e)

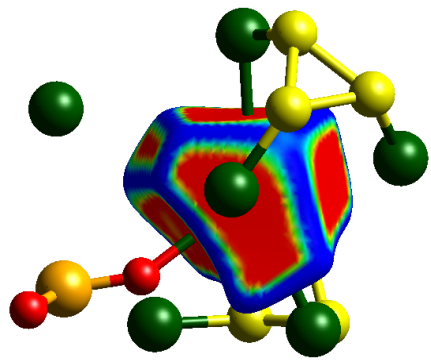

(h)

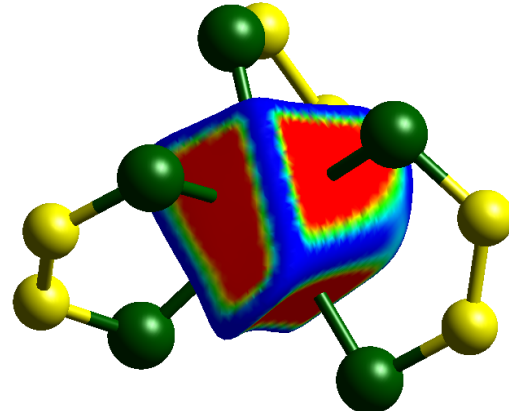

(c)

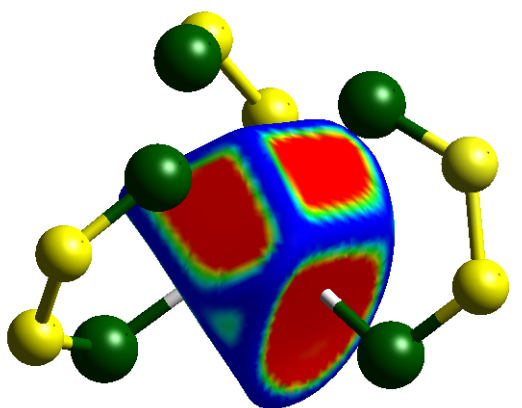

(f)

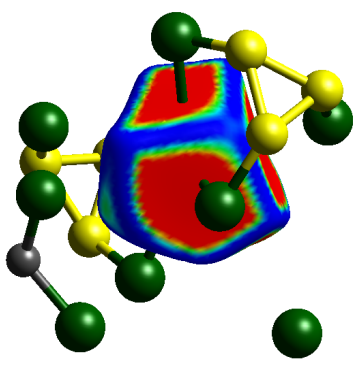

(i)

Figure 7. Curvedness plotted on atomic Hirshfeld surface and mapped from -1.4 (flat; red) to -0.3 (sphere-like; blue) for the silver atoms in (a) 4, (b) 5, (c) 6, (d) 7, (e) 8, (f) $\left[\mathrm{Ag}_{2}\left[\mathrm{~B}_{12} \mathrm{Cl}_{12}\right]\right]_{n}$, (g) $\left.\mathrm{Ag}\left(\mathrm{CH}_{3} \mathrm{CN}\right)\left[\left(\mathrm{Me}_{3} \mathrm{~N}\right) \mathrm{B}_{12} \mathrm{Cl}_{11}\right]\right]_{n}$ (only one of four symmetrically independent atoms is depicted), (h) $\left.\left[\mathrm{Ag}_{2}\left(\mathrm{SO}_{2}\right)\left[\left(\mathrm{Me}_{3} \mathrm{~N}\right) \mathrm{B}_{12} \mathrm{Cl}_{11}\right]_{2}\right] \cdot \mathrm{SO}_{2}\right\}_{n}$ (one of two symmetrically independent atoms is depicted), (i) $\left\{\left[\mathrm{Ag}\left[\left(\mathrm{Me}_{3} \mathrm{~N}\right) \mathrm{B}_{12} \mathrm{Cl}_{11}\right]\right] \cdot 0.5 \mathrm{CH}_{2} \mathrm{Cl}_{2}\right\}_{n}$ (one of two symmetrically independent atoms is depicted).

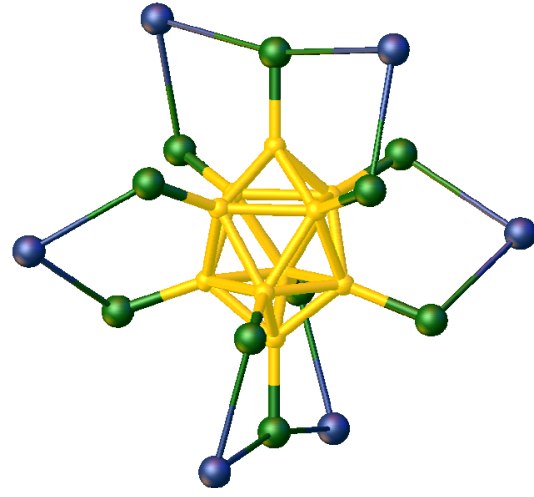

(a)

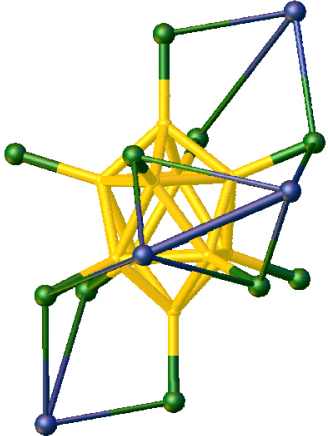

(b)

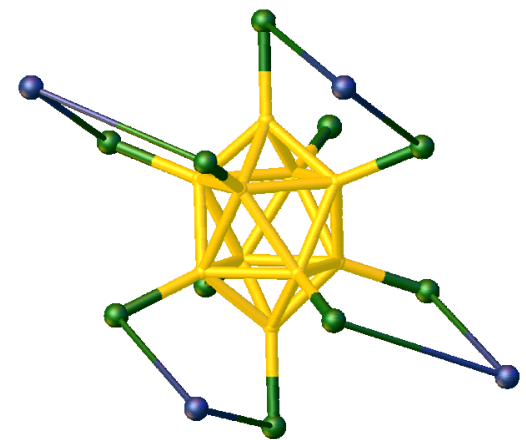

(c)

Figure 8. Coordination mode of $\left[\mathrm{B}_{10} \mathrm{Cl}_{10}\right]^{2-}$ in (a) 6, (b) 7, and (c) 8 . 


\section{Conclusions}

Silver(I) complexation with the $\left[\mathrm{B}_{10} \mathrm{Cl}_{10}\right]^{2-}$ anion was studied in the presence of $\mathrm{Ph}_{3} \mathrm{P}$ and without it. It was found that depending on the started $\mathrm{Ag}^{+} / \mathrm{Ph}_{3} \mathrm{P}$ ratio, compounds $\left.\mathrm{Ag}\left(\mathrm{PPh}_{3}\right)_{2}(\mathrm{DMF})_{2}\right]_{2}\left[\mathrm{~B}_{10} \mathrm{Cl}_{10}\right]$ or $\left[\mathrm{Ag}\left(\mathrm{Ph}_{3} \mathrm{P}\right)_{3}\left(\mathrm{H}_{2} \mathrm{O}\right)\right]_{2}\left[\mathrm{~B}_{10} \mathrm{Cl}_{10}\right]$ can be selectively isolated, both containing the uncoordinated boron cage. For comparison, the analogous reaction performed when using $\left[\mathrm{B}_{10} \mathrm{H}_{10}\right]^{2-}$ resulted in compound $\left[\mathrm{Ag}\left(\mathrm{Ph}_{3} \mathrm{P}\right)_{4}\right]\left[\mathrm{Ag}\left(\mathrm{Ph}_{3} \mathrm{P}\right)_{2}\left[\mathrm{~B}_{10} \mathrm{H}_{10}\right]\right]$, which contains silver mononuclear complexes: anionic $\left[\mathrm{Ag}\left(\mathrm{Ph}_{3} \mathrm{P}\right)_{2}\left[\mathrm{~B}_{10} \mathrm{H}_{10}\right]\right]^{-}$and cationic $\left[\mathrm{Ag}\left(\mathrm{Ph}_{3} \mathrm{P}\right)_{4}\right]^{+}$. The data obtained indicate lower coordination ability of the perchlorinated anion in silver(I) complexation in the presence of $\mathrm{Ph}_{3} \mathrm{P}$ as compared to the $\left[\mathrm{B}_{10} \mathrm{H}_{10}\right]^{2-}$ anion. However, $\left[\mathrm{B}_{10} \mathrm{Cl}_{10}\right]^{2-}$ can participate in coordination when the reaction is carried out at the absence of bulky cations and ligands in the reaction mixture. Three complexes with 3D frameworks were synthesized: $\left[\mathrm{Ag}_{2}\left[\mathrm{~B}_{10} \mathrm{Cl}_{10}\right]\right]_{n},\left[\mathrm{Ag}_{2}(\mathrm{DMF})_{2}\left[\mathrm{~B}_{10} \mathrm{Cl}_{10}\right]_{n}\right.$, and $\left[\mathrm{Ag}_{2}\left(\mathrm{CH}_{3} \mathrm{CN}\right)_{2}\left[\mathrm{~B}_{10} \mathrm{Cl}_{10}\right]\right]_{n}$ from water, $\mathrm{DMF}$, and acetonitrile, respectively. The boron cages are coordinated by silver; the $\mathrm{Ag}-\mathrm{Ag}$ bonds can be assumed in $\left[\mathrm{Ag}_{2}(\mathrm{DMF})_{2}\left[\mathrm{~B}_{10} \mathrm{Cl}_{10}\right]_{n}\right.$ based on the X-ray diffraction and Raman spectroscopy data. Note that copper(I) reactions in the presence of $\mathrm{Ph}_{3} \mathrm{P}$ result in preparation of mononuclear $\left[\mathrm{Cu}\left(\mathrm{Ph}_{3} \mathrm{P}\right)_{3} \mathrm{Cl}\right] \cdot 2 \mathrm{DMF}$ and binuclear $\left[\mathrm{Cu}_{2}\left(\mathrm{Ph}_{3} \mathrm{P}\right)_{3}(\mu-\mathrm{Cl})_{2}\right]$ copper(I) complexes rather than boron-containing complexes; the perchlorinated closo-decaborate anion remains unreacted.

Supplementary Materials: The following are available online at http://www.mdpi.com/2073-4352/10/5/389/s1, Figures S1-S7: IR spectra of complexes 1-8 and Raman spectra of complexes 6-8, Figures S8-S11: X-ray powder diffraction data for $1 \cdot 2 \mathrm{DMF}, \mathbf{4}, \mathbf{6}$, and 7, Figure S12: Calculated voids in solid 6.

Author Contributions: Conceptualization, V.V.A. and N.T.K.; methodology, V.V.A. and E.A.M.; synthesis and characterization, V.V.A. and E.A.M.; powder XRD studies, G.A.B.; XRD study, A.V.V.; writing- original draft preparation, V.V.A.; writing — review and editing, A.V.V.; visualization, A.V.V.; supervision, N.T.K. All authors have read and agreed to the published version of the manuscript.

Funding: Synthesis of silver containing compounds was funded by the Council for Grants of the President of RF for State Support of Scientific Research Performed by Young Russian Scientists, grant number MD-265.2019.3. The authors acknowledge the financial support from the Ministry of Science and Higher Education of the Russian Federation. The X-ray powder diffraction studies were performed within the framework of the State Assignment of the Kurnakov Institute in the field of fundamental scientific research. X-ray single-crystal diffraction studies were carried our using the equipment of Center for molecular composition studies of INEOS RAS.

Acknowledgments: The authors thank L.V. Goeva (the Kurnakov Institute) and O.N. Belousova (the Kurnakov Institute) for spectroscopic studies.

Conflicts of Interest: The authors declare no conflict of interest.

\section{References}

1. Krishnan, K.M. Fundamentals and Applications of Magnetic Materials; Oxford University Press: Oxford, UK, 2016.

2. Muetterties, E.L.; Knoth, W.H. Polyhedral Boranes; Dekker: New York, NY, USA, 1968.

3. Greenwood, N.N.; Earnshaw, A. Chemistry of the Elements, 2nd ed.; Butterworth-Heinemann: Oxford, $\mathrm{UK}, 1997$.

4. Boron Science: New Technologies and Applications; Hosmane, N.S. (Ed.) CRC Press: Boca Raton, FL, USA, 2012.

5. Zhizhin, K.Y.; Zhdanov, A.P.; Kuznetsov, N.T. Derivatives of closo-decaborate anion $\left[\mathrm{B}_{10} \mathrm{H}_{10}\right]^{2-}$ with exo-polyhedral substituents. Russ. J. Inorg. Chem. 2010, 55, 2089-2127. [CrossRef]

6. Sivaev, I.B.; Prikaznov, A.V.; Naoufal, D. Fifty years of the closo-decaborate anion chemistry. Coll. Czech. Chem. Commun. 2010, 75, 1149-1199. [CrossRef]

7. Sivaev, I.B.; Bregadze, V.I.; Sjöberg, S. Chemistry of closo-Dodecaborate Anion $\left[\mathrm{B}_{12} \mathrm{H}_{12}\right]^{2-}$ : A Review. Collect. Czech. Chem. Commun. 2002, 67, 679-727. [CrossRef]

8. Avdeeva, V.V.; Malinina, E.A.; Sivaev, I.B.; Bregadze, V.I.; Kuznetsov, N.T. Silver and copper complexes with closo-polyhedral borane, carborane and metallacarborane anions: Synthesis and X-ray structure. Crystals 2016, 6, 60. [CrossRef]

9. Malinina, E.A.; Avdeeva, V.V.; Goeva, L.V.; Kuznetsov, N.T. Coordination compounds of electron-deficient boron cluster anions $\mathrm{B}_{n} \mathrm{H}_{n}{ }^{2-}(n=6,10,12)$. Russ. J. Inorg. Chem. 2010, 55, 2148-2202. [CrossRef] 
10. Avdeeva, V.V.; Malinina, E.A.; Kuznetsov, N.T. Coordination chemistry of iron triad metals with organic $\mathrm{N}$-donor ligands and boron cluster anions $\left[\mathrm{B}_{10} \mathrm{H}_{10}\right]^{2-},\left[\mathrm{B}_{12} \mathrm{H}_{12}\right]^{2-}$, and $\left[\mathrm{B}_{10} \mathrm{Cl}_{10}\right]^{2-}$ : Complexation and accompanying processes. Rus. J. Inorg. Chem. 2017, 62, 1673-1702. [CrossRef]

11. Goswami, L.N.; Ma, L.; Chakravarty, S.; Cai, Q.; Jalisatgi, S.S.; Hawthorne, M.F. Discrete Nanomolecular Polyhedral Borane Scaffold Supporting Multiple Gadolinium(III) Complexes as a High Performance MRI Contrast Agent. Inorg. Chem. 2013, 52, 1694-1700. [CrossRef]

12. Plesek, J. Potential applications of the boron cluster compounds. Chem. Rev. 1992, 92, 269-278. [CrossRef]

13. Sivaev, I.B.; Bregadze, V.I.; Kuznetsov, N.T. Derivatives of the closo-dodecaborate anion and their application in medicine. Russ. Chem. Bull. 2002, 51, 1362-1374. [CrossRef]

14. Sivaev, I.B.; Bregadze, V.I. Polyhedral boranes for medical applications: Current status and perspectives. Eur. J. Inorg. Chem. 2009, 11, 1433-1450. [CrossRef]

15. Teixidor, F.; Vinas, C.; Demonceau, A.; Nunez, R. Boron clusters: Do they receive the deserved interest? Pure Appl. Chem. 2003, 75, 1305-1313. [CrossRef]

16. Avdeeva, V.V.; Malinina, E.A.; Kuznetsov, N.T. Isomerism in complexes with the decahydro-closo-decaborate anion. Polyhedron 2016, 105, 205-221. [CrossRef]

17. Avdeeva, V.V.; Polyakova, I.N.; Vologzhanina, A.V.; Malinina, E.A.; Zhizhin, K.Y.; Kuznetsov, N.T. Positional isomers of mononuclear silver(I) anionic complex $\left[\mathrm{Ag}\left(\mathrm{Ph}_{3} \mathrm{P}\right)_{2}\left(\mathrm{~B}_{10} \mathrm{H}_{10-\mathrm{x}} \mathrm{Cl}_{\mathrm{x}}\right)\right]^{-}(\mathrm{x}=0$ or 1$)$ with apically and equatorially coordinated decahydro-closo-decaborate and 2-chlorononahydro-closo-decaborate ligands. Polyhedron 2017, 123, 396-403. [CrossRef]

18. Avdeeva, V.V.; Buzin, M.I.; Dmitrienko, A.O.; Dorovatovskii, P.V.; Malinina, E.A.; Kuznetsov, N.T.; Voronova, E.D.; Zubavichus, Y.V.; Vologzhanina, A.V. Solid-State Reactions of Eicosaborate $\left[\mathrm{B}_{20} \mathrm{H}_{18}\right]^{2-}$ Salts and Complexes. Chem. Eur. J. 2017, 23, 16819-16828. [CrossRef] [PubMed]

19. Reed, C.A. Carboranes: A new class of weakly coordinating anions for strong electrophiles, oxidants, and superacids. Acc. Chem. Res. 1998, 31, 133-139. [CrossRef]

20. Strauss, S.H. Search for larger and more weakly coordinating anions. Chem. Rev. 1993, 93, 927-942. [CrossRef]

21. Knapp, C. Comprehensive Inorganic Chemistry II; Elsevier: Amsterdam, The Netherlands, 2013; Volume 1, pp. 651-679.

22. Engesser, T.A.; Lichtenthaler, M.R.; Schleep, M.; Krossing, I. Reactive p-Block cations stabilized by weakly coordinating anions. Chem. Soc. Rev. 2016, 45, 789-899. [CrossRef]

23. Avdeeva, V.V.; Kravchenko, E.A.; Gippius, A.A.; Vologzhanina, A.V.; Malinina, E.A.; Zhurenko, S.V.; Buzanov, G.A.; Kuznetsov, N.T. Decachloro-closo-decaborate anion in copper(II) complexation reactions with N-donor ligands: ${ }^{35} \mathrm{Cl} \mathrm{NQR}$ and X-ray studies. Polyhedron 2017, 127, 238-247. [CrossRef]

24. Avdeeva, V.V.; Vologzhanina, A.V.; Goeva, L.V.; Malinina, E.A.; Kuznetsov, N.T. Reactivity of boron cluster anions $\left[\mathrm{B}_{10} \mathrm{H}_{10}\right]^{2-},\left[\mathrm{B}_{10} \mathrm{Cl}_{10}\right]^{2-}$ and $\left[\mathrm{B}_{12} \mathrm{H}_{12}\right]^{2-}$ in cobalt(II)/cobalt(III) complexation with 1,10-phenanthroline. Inorg. Chim. Acta 2015, 428, 154-162. [CrossRef]

25. Avdeeva, V.V.; Vologzhanina, A.V.; Malinina, E.A.; Zhizhin, K.Y.; Kuznetsov, N.T. Boron Cluster Anions $\left[\mathrm{B}_{10} \mathrm{X}_{10}\right]^{2-}(\mathrm{X}=\mathrm{H}, \mathrm{Cl})$ in Manganese(II) Complexation with 2,2'-Bipyridyl. Russ. J. Coord. Chem. 2019, 45, 301-306. [CrossRef]

26. Kravchenko, E.A.; Gippius, A.A.; Korlyukov, A.A.; Vologzhanina, A.V.; Avdeeva, V.V.; Malinina, E.A.; Ulitin, E.O.; Kuznetsov, N.T. Secondary interactions in decachloro-closo-decaborates $\mathrm{R}_{2}\left[\mathrm{~B}_{10} \mathrm{Cl}_{10}\right]$ $\left(\mathrm{R}=\left[\mathrm{Ag}\left(\mathrm{NH}_{3}\right)_{2}\right]^{+}, \mathrm{Ph}_{4} \mathrm{P}^{+}, \mathrm{Et}_{3} \mathrm{NH}^{+}\right):{ }^{35} \mathrm{Cl} \mathrm{NQR}, \mathrm{PW}-\mathrm{DFT}$, and X-ray studies. Inorg. Chim. Acta 2016, 447, 22-31. [CrossRef]

27. Groom, C.R.; Bruno, I.J.; Lightfoot, M.P.; Ward, S.C. The Cambridge structural database. Acta Crystallogr. Sect. B 2016, 72, 171-179. [CrossRef] [PubMed]

28. Saleh, M.; Powell, D.R.; Wehmschulte, R.J. Chlorination of 1-Carba-closo-dodecaborate and 1-Ammonio-closo-dodecaborate Anions. Inorg. Chem. 2016, 55, 10617-10627. [CrossRef] [PubMed]

29. Hague, C.; Patmore, N.J.; Frost, C.G.; Mahon, M.F.; Weller, A.S. [( $\left.\left.\mathrm{PPh}_{3}\right) \mathrm{Ag}\left(\mathrm{CB}_{11} \mathrm{H}_{6} \mathrm{Y}_{6}\right)\right](\mathrm{Y}=\mathrm{H}, \mathrm{Br}): \mathrm{Highly}$ active, selective and recyclable Lewis acids for a hetero-Diels-Alder reaction. Chem. Commun. 2001, 21, 2286-2287. [CrossRef]

30. Patmore, N.J.; Ingleson, M.J.; Mahon, M.F.; Weller, A.S. Investigation of the synthesis of $\left\{\mathrm{Mo}\left(\eta_{5}-\mathrm{C}_{5} \mathrm{H}_{5}\right)(\mathrm{CO})_{3}\right\}^{+}$ fragments partnered with the monoanionic carboranes $\left[\text { closo- } \mathrm{CB}_{11} \mathrm{H}_{11} \mathrm{Br}\right]^{-}, \quad\left[\text { closo- } \mathrm{CB}_{11} \mathrm{H}_{6} \mathrm{Br}_{6}\right]^{-}$and [closo- $\left.\mathrm{HCB}_{11} \mathrm{Me}_{11}\right]^{-}$by silver salt metathesis and hydride abstraction. Dalton Trans. 2003, 14, 2894-2904. [CrossRef] 
31. Cunha-Silva, L.; Carr, M.J.; Kennedy, J.D.; Hardie, M.J. Silver-Dabco Coordination Networks with Distinct

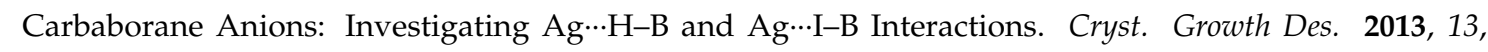
3162-3170. [CrossRef]

32. Jenne, C.; Wegener, B. Silver Salts of the Weakly Coordinating Anion $\left[\mathrm{Me}_{3} \mathrm{NB}_{12} \mathrm{Cl}_{11}\right]^{-}$. Z. Anorg. Allg. Chem. 2018, 644, 1123-1132. [CrossRef]

33. Tsang, C.-W.; Yang, Q.; Sze, E.T.-P.; Mak, T.C.W.; Chan, D.T.W.; Xie, Z. Weakly Coordinating Nature of a Carborane Cage Bearing Different Halogen Atoms. Synthesis and Structural Characterization of Icosahedral Mixed Halocarborane Anions, 1-H- $\mathrm{CB}_{11} \mathrm{Y}_{5} \mathrm{X}_{6}{ }^{-}(\mathrm{X}, \mathrm{Y}=\mathrm{Cl}$, Br, I). Inorg. Chem. 2000, 39, 5851-5858. [CrossRef]

34. Tiritiris, I.; Schleid, T. The Crystal Structure of Solvent-Free Silver Dodecachloro-closo-dodecaborate $\mathrm{Ag}_{2}\left[\mathrm{~B}_{12} \mathrm{Cl}_{12}\right]$ from Aqueous Solution. Z. Anorg. Allg. Chem. 2003, 629, 581-583. [CrossRef]

35. Volkov, O.; Hu, C.; Paetzold, P. Silver-Hydrogen Interactions in Crystalline Silver Dodecahydrododecaborates. Z. Anorg. Allg. Chem. 2005, 631, 1107-1112. [CrossRef]

36. Hawthorne, M.F.; Pitochelli, A.R. The reaction of bis-acetonitrile decaborane with amines. J. Am. Chem. Soc. 1959, 81, 5519. [CrossRef]

37. Knoth, W.H.; Miller, H.C.; Sauer, J.C.; Balthis, J.H.; Chia, Y.T.; Muetterties, E.L. Chemistry of Boranes. IV. Halogenation of $\mathrm{B}_{10} \mathrm{H}_{10}{ }^{2-}$ and $\mathrm{B}_{12} \mathrm{H}_{12}{ }^{2-}$. Inorg. Chem. 1964, 3, 159-167. [CrossRef]

38. Barron, P.F.; Dyason, J.C.; Healy, P.C.; Engelhardt, L.M.; Skelton, B.W.; White, A.H. Lewis base adducts of Group 11 metal compounds. Part 24. Co-ordination of triphenylphosphine with silver nitrate. A solid-state cross-polarization magic angle spinning ${ }^{31} \mathrm{P}$ nuclear magnetic resonance, crystal structure, and infrared spectroscopic study of $\mathrm{Ag}\left(\mathrm{PPh}_{3}\right)_{3} \mathrm{NO}_{3}(\mathrm{n}=1-4)$. J. Chem. Soc. Dalton Trans. 1986, 1965-1970. [CrossRef]

39. Barron, P.F.; Dyason, J.C.; Healy, P.C.; Engelhardt, L.M.; Pakawatchai, C.; Patrick, V.A.; White, A.H. Lewis-base adducts of Group 11 metal(I) compounds. Part 28. Solid-state phosphorus-31 cross-polarization magic-angle spinning nuclear magnetic resonance and structural studies on the mononuclear 3:1 adducts of triphenylphosphine with copper(I) halides. J. Chem. Soc. Dalton Trans. 1987, 1099-1106. [CrossRef]

40. Sheldrick, G.M. Crystal structure refinement with SHELXL. Acta Crystallogr. Sect. C 2015, 71, 3-7. [CrossRef]

41. Dolomanov, O.V.; Bourhis, L.J.; Gildea, R.J.; Howard, J.A.K.; Puschmann, H. OLEX2: A complete structure solution, refinement and analysis program. J. Appl. Cryst. 2009, 42, 339-341. [CrossRef]

42. Schaper, T.; Preetz, W. Hexahydro-closo-hexaborate as a ligand in coordination compounds: Syntheses and crystal structure of $\left[\mathrm{M}_{2}\left(\mu-\right.\right.$ bis- $\left.\left.\eta^{3}-\mathrm{B}_{6} \mathrm{H}_{6}\right)\left(\mathrm{PPh}_{3}\right)_{2}\right](\mathrm{M}=\mathrm{Cu}, \mathrm{Au})$. Chem. Ber. 1997, 130, 405-408. [CrossRef]

43. Kabbani, R.F.; Rheingold, A.L.; Lam, K.-C.; Margulis, Y.; Vovchenko, M. Synthesis and Crystal Structure of a New Hexahydro-closo-hexaborate Copper(I) Complex $\mathrm{Cu}_{2}\left[\left(\mathrm{C}_{6} \mathrm{H}_{5}\right)_{3} \mathrm{P}\right]_{4} \mathrm{~B}_{6} \mathrm{H}_{6}$. Inorg. Chem. 1999, 38, 3748-3750. [CrossRef]

44. Gill, J.T.; Lippard, S.J. Transition metal hydroborate complexes. VIII. Structure of $\left[\left(\mathrm{PPh}_{3}\right)_{2} \mathrm{Cu}\right]_{2} \mathrm{~B}_{10} \mathrm{H}_{10} \cdot \mathrm{CHCl}_{3}$. Inorg. Chem. 1975, 14, 751-761. [CrossRef]

45. Drozdova, V.V.; Malinina, E.A.; Polyakova, I.N.; Kuznetsov, N.T. Coordination Isomerism in Complexes of IB Group Metals with the closo-Decaborate Anion $\left[\mathrm{B}_{10} \mathrm{H}_{10}\right]^{2-}$ and Triphenylphosphine. Dokl. Chem. 2008, 418, 30-33. [CrossRef]

46. Chaozhou, N.; Yilin, M.; Cuifang, S. Crystal and molecular structure of $\left[\left(\mathrm{C}_{6} \mathrm{H}_{5}\right)_{3} \mathrm{P}\right]_{2} \mathrm{Cu}_{2} \mathrm{~B}_{12} \mathrm{H}_{12}$. Acta Chim. Sin. 1985, 43, 411.

47. Lazarou, K.; Bednarz, B.; Kubicki, M.; Verginadis, I.I.; Charalabopoulos, K.; Kourkoumelis, N.; Hadjikakou, S.K. Structural, photolysis and biological studies of the bis( $\mu_{2}$-chloro)-tris(triphenylphosphine)di-copper(I) and chloro-tris(triphenylphosphine)-copper(I) complexes. Study of copper(I)-copper(I) interactions. Inorg. Chim. Acta 2010, 363, 763-772. [CrossRef]

48. Folting, K.; Huffman, J.; Mahoney, W.; Stryker, J.M.; Caulton, K.G. Structure of chlorotris(triphenylphosphine) copper(I)-tetrahydrofuran (1/3). Acta Crystallogr. Sect. C 1987, 43, 1490-1492. [CrossRef]

49. Krauter, T.; Neumuller, B. Triphenylphosphane complexes of copper(I): Structural and ${ }^{31}$ P NMR investigations. Polyhedron 1996, 15, 2851-2857. [CrossRef]

50. Muetterties, E.L.; Balthis, J.H.; Chia, Y.T.; Knoth, W.H.; Miller, H.C. Chemistry of Boranes. VIII. Salts and Acids of $\mathrm{B}_{10} \mathrm{H}_{10}{ }^{-2}$ and $\mathrm{B}_{12} \mathrm{H}_{12}{ }^{-2}$. Inorg. Chem. 1964, 3, 444-451. [CrossRef]

51. Malinina, E.A.; Zhizhin, K.Y.; Polyakova, I.N.; Lisovskiy, M.V.; Mustyatsa, V.N.; Kuznetsov, N.T. Silver(I) and copper(I) complexes with the closo-decoborate anion $\mathrm{B}_{10} \mathrm{H}_{10}{ }^{2-}$ as a ligand. Russ. J. Inorg. Chem. 2002, 47, 1158-1167. 
52. Paskevicius, M.; Hansen, B.R.S.; Jørgensen, M.; Richter, B.; Jensen, T.R. Multifunctionality of silver closo-boranes. Nat. Commun. 2017, 8, 15136. [CrossRef]

53. Polyakova, I.N.; Malinina, E.A.; Drozdova, V.V.; Kuznetsov, N.T. Crystal structure of ( $\mu 5$-decahydrocloso-decaborato) ( $\mu^{2}$-O-dimethylformamide)disilver(I) $\left[\mathrm{Ag}_{2}\left(\mathrm{~B}_{10} \mathrm{H}_{10}\right)(\mathrm{DMF})\right]$. Crystallogr. Rep. 2008, 53, 253-256. [CrossRef]

54. Kravchenko, E.A.; Gippius, A.A.; Vologzhanina, A.V.; Avdeeva, V.V.; Malinina, E.A.; Kuznetsov, N.T. Secondary interactions in decachloro-closo-decaborates of alkali metals $\mathrm{M}_{2}\left[\mathrm{~B}_{10} \mathrm{Cl}_{10}\right]\left(\mathrm{M}=\mathrm{K}^{+}\right.$and $\left.\mathrm{Cs}^{+}\right):{ }^{35} \mathrm{Cl}$ NQR and X-ray studies. Polyhedron 2016, 117, 561-568. [CrossRef]

55. Muetterties, E.L.; Merrifield, R.E.; Miller, H.C.; Knoth, W.H., Jr.; Downin, J.R. Chemistry of Boranes. III. The Infrared and Raman Spectra of $\mathrm{B}_{12} \mathrm{H}_{12}{ }^{-}$and Related Anions. J. Am. Chem. Soc. 1962, 84, 2506-2508. [CrossRef]

56. Martina, I.; Wiesinger, R.; Jembrih-Simbürger, D.; Schreiner, M. Micro-raman characterisation of silver corrosion products: Instrumental set up and reference Database. E-Preserv. Sci. 2012, 9, 1-8.

57. Kravchenko, E.A.; Gippius, A.A.; Vologzhanina, A.V.; Avdeeva, V.V.; Malinina, E.A.; Demikhov, E.I.; Kuznetsov, N.T. Secondary interactions as defined by ${ }^{35} \mathrm{Cl}$ NQR spectra in cesium decachloro-closodecaborates prepared in non-aqueous solutions. Polyhedron 2017, 138, 140-144. [CrossRef]

58. Vologzhanina, A.V.; Korlyukov, A.A.; Avdeeva, V.V.; Polyakova, I.N.; Malinina, E.A.; Kuznetsov, N.T. Theoretical QTAIM, ELI-D, and Hirshfeld Surface Analysis of the $\mathrm{Cu}-(\mathrm{H}) \mathrm{B}$ Interaction in $\left[\mathrm{Cu}_{2}(\mathrm{bipy})_{2} \mathrm{~B}_{10} \mathrm{H}_{10}\right]$. J. Phys. Chem. A 2013, 117, 13138-13150. [CrossRef] [PubMed]

59. Smol'yakov, A.F.; Korlyukov, A.A.; Dolgushin, F.M.; Balagurova, E.V.; Chizhevsky, I.T.; Vologzhanina, A.V. Studies of Multicenter and Intermolecular Dihydrogen B-H $\cdots \mathrm{H}-\mathrm{C}$ Bonding in $\left[4,8,8^{\prime}-\mathrm{exo}-\left\{\mathrm{PPh}_{3} \mathrm{Cu}\right\}-\right.$

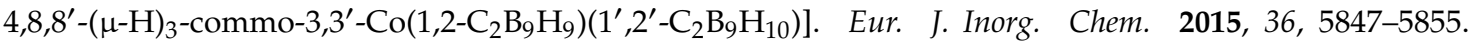
[CrossRef]

60. Savchenkov, A.V.; Klepov, V.V.; Vologzhanina, A.V.; Serezhkina, L.B.; Pushkin, D.V.; Serezhkin, V.N. Trinuclear $\left\{\mathrm{Sr}\left[\mathrm{UO}_{2} \mathrm{~L}_{3}\right]_{2}\left(\mathrm{H}_{2} \mathrm{O}\right)_{4}\right\}$ and pentanuclear $\left\{\mathrm{Sr}\left[\mathrm{UO}_{2} \mathrm{~L}_{3}\right]_{4}\right\}^{2-}$ uranyl monocarboxylate complexes (L-acetate or n-butyrate ion). CrystEngComm 2015, 17, 740-746. [CrossRef]

61. Kalaj, M.; Karter, K.P.; Savchenkov, A.V.; Pyrch, M.M.; Cahill, C.C. Syntheses, Structures, and Comparisons of Heterometallic Uranyl Iodobenzoates with Monovalent Cations. Inorg. Chem. 2017, 56, 9156-9168. [CrossRef]

62. Skovsen, I.; Christensen, M.; Clausen, H.F.; Overgaard, J.; Stiewe, C.; Desgupta, T.; Mueller, E.; Spackman, M.A.; Iversen, B.B. Synthesis, Crystal Structure, Atomic Hirshfeld Surfaces, and Physical Properties of Hexagonal CeMnNi 4 . Inorg. Chem. 2010, 49, 9343-9349. [CrossRef]

63. Jørgensen, M.R.V.; Skovsen, I.; Clausen, H.F.; Mi, J.-L.; Christensen, M.; Nishibori, E.; Spackman, M.A.; Iversen, B.B. Application of Atomic Hirshfeld Surface Analysis to Intermetallic Systems: Is Mn in Cubic $\mathrm{CeMnNi}_{4}$ a Thermoelectric Rattler atom? Inorg. Chem. 2012, 51, 1916-1924. [CrossRef]

64. Kastbjerg, S.; Uvarov, C.A.; Kauzlarich, S.M.; Chen, Y.-S.; Nishibori, E.; Spackman, M.A.; Iversen, B.B. Crystal structure and chemical bonding of the intermetallic Zintl phase $\mathrm{Yb}_{11} \mathrm{AlSb}_{9}$. Dalton Trans. 2012, 41, 10347-10353. [CrossRef]

65. Turner, M.J.; McKinnon, J.J.; Wolff, S.K.; Grimwood, D.J.; Spackman, P.R.; Jayatilaka, D.; Spackman, M.A. CrystalExplorer17 (2017). University of Western Australia. Available online: http://hirshfeldsurface.net (accessed on 20 April 2020).

66. Roy, D.; Furtak, T.E. Evidence for Ag cluster vibrations in enhanced Raman scattering from the Ag/Electrolyte Interface. Chem. Phys. Lett. 1986, 124, 299-303. [CrossRef]

(C) 2020 by the authors. Licensee MDPI, Basel, Switzerland. This article is an open access article distributed under the terms and conditions of the Creative Commons Attribution (CC BY) license (http://creativecommons.org/licenses/by/4.0/). 